bioRxiv preprint doi: https://doi.org/10.1101/263624; this version posted February 11,2018 . The copyright holder for this preprint (which was not certified by peer review) is the author/funder, who has granted bioRxiv a license to display the preprint in perpetuity. It is made available under aCC-BY-NC-ND 4.0 International license.

Recognition of acetyllysine by the ATAD2B bromodomain

\title{
Structural insights into the recognition of mono- and di-acetyllysine by the ATAD2B bromodomain
}

Jonathan T. Lloyd ${ }^{1}$, Jamie C. Gay ${ }^{1 \#}$, Marco Tonelli ${ }^{2}$, Gabriel Cornilescu ${ }^{2}$, Paul Nguyen ${ }^{1}$, Samuel Carlson ${ }^{1}$, John L. Markley ${ }^{2}$ and Karen C. Glass ${ }^{1 *}$

${ }^{1}$ From the Department of Pharmaceutical Sciences, Albany College of Pharmacy and Health Sciences, Colchester, VT, 05446, USA

${ }^{2}$ National Magnetic Resonance Facility at Madison and Department of Biochemistry, University of Wisconsin-Madison, Madison, WI, 53706, USA

Running title: Recognition of acetyllysine by the ATAD2B bromodomain

*To whom correspondence should be addressed: Karen C. Glass, Department of Pharmaceutical Science, Albany College of Pharmacy and Health Sciences, 261 Mountain View Dr., Colchester, VT 05446, USA, Tel.: 802-735-2636; Fax: 802-654-0716; E-mail: karen.glass@acphs.edu

${ }^{\#}$ Current address: Department of Medical Laboratory and Radiation Sciences, University of Vermont, Burlington, VT 05405, USA

ABSTRACT: The ATPase family, $\mathrm{AAA}^{+}$domain-containing protein 2B (ATAD2B) is a nuclear protein that may play a role in the development of neuronal tissues and tumorigenesis. The ATAD2B protein contains a C-terminal bromodomain that is highly homologous to the ATAD2 bromodomain, with $74.7 \%$ sequence identity and $94.4 \%$ similarity. The ATAD2 bromodomain is an attractive drug target because overexpression of ATAD2 is positively correlated with the progression of multiple cancer types, and poor patient outcomes. Although ATAD2 and ATAD2B are highly conserved, little is known about the function of ATAD2B, or its role in oncogenesis. We hypothesized that the ATAD2B bromodomain would likely be involved in recognition of di-acetyllysine modifications on the histone tail, similarly to its ATAD2 paralog. We identified the acetylated histone ligands of the ATAD2B bromodomain using a combination of isothermal titration calorimetry and nuclear magnetic resonance techniques. Interestingly, the ATAD2B bromodomain has different substrate specificity than the ATAD2 bromodomain, preferentially selecting for the histone H4K5acK8ac ligand. NMR chemical shift perturbation assays and site-directed mutagenesis were used to map out the acetyllysine binding pocket, enabling characterization of residues involved in coordination of mono- and di-acetylated histone ligands by the ATAD2B bromodomain. In addition, the X-ray crystal structure of the ATAD2B bromodomain in complex with an ATAD2 bromodomain inhibitor was solved at $2.2 \AA$ resolution. This structure revealed that critical contacts required for bromodomain inhibitor coordination are conserved between the ATAD2/B bromodomains, and many of these residues play a dual role in acetyllysine recognition.

\section{HIGHLIGHTS:}

- The ATAD2B bromodomain recognizes mono- and di-acetylated histone ligands.

- Chemical shift maps outline the ATAD2B bromodomain acetyllysine binding pocket.

- An ATAD2B bromodomain-inhibitor complex reveals important binding contacts.

KEYWORDS: Acetyllysine; bromodomain; chromatin reader domain; epigenetics; histone; posttranslational modification

\section{ABREVIATIONS:}

ATAD2-ATPase family $\mathrm{AAA}^{+}$domain containing 2

ATAD2B-ATPase family $\mathrm{AAA}^{+}$domain containing $2 \mathrm{~B}$

BRD-bromodomain 
bioRxiv preprint doi: https://doi.org/10.1101/263624; this version posted February 11,2018 . The copyright holder for this preprint (which was not certified by peer review) is the author/funder, who has granted bioRxiv a license to display the preprint in perpetuity. It is made available under aCC-BY-NC-ND 4.0 International license.

Recognition of acetyllysine by the ATAD2B bromodomain

BRPF1/3-Bromodomain and PHD finger containing protein 1/3

CD-circular dichroism

GST- glutathione-S-transferase

HSQC- heteronuclear single quantum coherence

ITC-isothermal titration calorimetry

NMR-nuclear magnetic resonance

PHD- plant homeodomain

PTMs-post-translational modifications

INTRODUCTION: The ATPase family, $\mathrm{AAA}^{+}$domain-containing protein 2B (ATAD2B, also known as KIAA1240), is a nuclear protein that contains two conserved domains: an $\mathrm{AAA}^{+}$ATPase domain and a bromodomain (Fig. 1A) [1]. Little is known about the biological function of the ATAD2B protein, but a study by Leachman et al., 2010 [1] indicates that ATAD2B is primarily found in neuronal tissue and may play a role in tumor progression. The $\mathrm{AAA}^{+}$or 'ATPases associated with diverse cellular activities' domain is found in a large superfamily of proteins that typically form a hexameric complex, able to recognize ATP, in order to drive molecular remodeling reactions [2]. Bromodomains are chromatin reader modules that are known to recognize acetylated lysine on the N-terminal tails of histone proteins [3], and function to bridge the associated bromodomain-containing protein or associated protein complexes, to specific genomic locations. Thus, recognition of acetyllysine modifications is an important epigenetic signaling pathway that often regulates global cellular processes including chromatin remodeling, gene expression, DNA replication, cellular growth and proliferation [4-9].

In humans, there are 61 known bromodomains that are found in 46 different proteins [10]. These bromodomains are divided into eight sub-families based on sequence and structural features [10]. The ATAD2B bromodomain falls into sub-family IV, which also includes the bromodomain-containing proteins ATAD2, BRPF1, BRD1, BRPF3, BRD7 and BRD9. The acetyllysine binding activity of many of the family IV bromodomain-containing proteins has been at least partially characterized through high throughput histone peptide arrays and biochemical and biophysical approaches (see Lloyd et al., 2017 [11] for a recent review) [10-17]. The bromodomains in subfamily IV recognize mono- and diacetyllysines on histones H2A, H3 and H4 (Fig. 1B). Interestingly, the BRD9 bromodomain is also able to bind to larger acyl groups including propionylated and butyrylated lysine residues [12]. The C-terminal bromodomain of ATAD2B is highly homologous to the ATAD2 bromodomain, with $74.7 \%$ sequence identity and $94.4 \%$ similarity [1]. The ATAD2 bromodomain binds to acetylated histones at H4K5ac and H4K12ac, and X-ray crystal structures have elucidated essential features of the binding pocket that are important for ligand coordination $[15,16]$. Recently, the ATAD2 bromodomain was shown to recognize di-acetylated histones, and it associates with H4K5acK12ac modifications found on newly synthesized histones following DNA replication [17]. However, the acetylated histone ligands of the ATAD2B bromodomain have yet to be determined, and the molecular mechanism(s) underlying acetyllysine recognition are currently unclear.

Understanding the similarities and differences between the ATAD2 and ATAD2B (ATAD2/B) bromodomains is very important because ATAD2 is considered to be a critical transcription factor in malignant cells that up-regulates anti-apoptotic activity in both prostate and breast cancer cells $[18,19]$. ATAD2 has become an exciting new epigenetic target due to its over-expression and association with multiple cancers, including breast and prostate cancer, ovarian and endometrial carcinoma, as well as gastric, colorectal and cervical cancers [20-24]. Bromodomain inhibitors for ATAD2 are currently being developed [15, 25-27], and to further progress the research being done on ATAD2 bromodomain inhibitors it will be vital to fully characterize the closely related ATAD2B bromodomain paralog. This information will ultimately contribute to the development of more potent and selective inhibitors targeting these bromodomains. 
bioRxiv preprint doi: https://doi.org/10.1101/263624; this version posted February 11,2018 . The copyright holder for this preprint (which was not certified by peer review) is the author/funder, who has granted bioRxiv a license to display the preprint in perpetuity. It is made available under aCC-BY-NC-ND 4.0 International license.

Recognition of acetyllysine by the ATAD2B bromodomain

We hypothesized that the ATAD2B bromodomain would likely be involved in recognition of diacetyllysine modifications on the histone tail, similarly to its ATAD2 paralog [17]. In order to outline the function of the ATAD2B bromodomain, we used isothermal titration calorimetry (ITC) and nuclear magnetic resonance (NMR) to screen the purified bromodomain against a large number of acetylated histone tail peptides in vitro. We discovered that the ATAD2B bromodomain recognizes acetylated lysine residues on the N-terminal tails of histones $\mathrm{H} 4$ and $\mathrm{H} 2 \mathrm{~A}$. ITC was used to characterize the binding affinities of the ATAD2B bromodomain with histone peptide ligands, and we found that the di-acetylated histone H4K5acK8ac was the strongest binder. Since the molecular details of di-acetyllysine recognition had not been determined, we used NMR chemical shift perturbation experiments to map out the acetyllysine binding pocket on the apo ATAD2B bromodomain structure. This allowed us to identify amino acid residues outside of the canonical acetyllysine binding site that are altered in the presence of di-acetyllysine ligands. Site directed mutagenesis coupled to ITC experiments confirmed the role of residues in the bromodomain-binding pocket in ligand coordination. X-ray crystallography was used to solve the structure the ATAD2B bromodomain in complex with compound 38, an ATAD2 bromodomain inhibitor developed by GlaxoSmithKline [25]. From this structure we outlined the molecular contacts important for inhibitor coordination that are conserved between the ATAD2/B bromodomains, and many of these residues play a role in acetyllysine recognition. Our research supports a model whereby inherent flexibility in the ATAD2/B bromodomain ZA and BC loop regions is important for recruiting acetyllysine ligands into the bromodomain binding pocket. Our results establish key differences in the histone binding specificity of the ATAD2/B bromodomains, suggesting that these proteins carry out divergent functions within the cell. These data advance our understanding of how the ATAD2B bromodomain recognizes and selects for specific acetyllysine modifications, and provides new information that will inform the design of small molecule compounds to specifically select for the ATAD2/B bromodomains.

\section{RESULTS:}

\section{The ATAD2B bromodomain recognizes mono- and di-acetylated histones}

Bromodomains are known as acetyllysine reader domains [3], however, the histone ligands of the ATAD2B bromodomain have yet to be determined. We used a combination of NMR and ITC methods to identify the acetyllysine modifications recognized by the ATAD2B bromodomain. We screened the ATAD2B bromodomain against a large number of unmodified, mono-acetylated and di-acetylated histone ligands to test its binding activity (Table 1 and Fig. 2). Interestingly, the ATAD2B bromodomain appears to be a di-acetyllysine reader and binds to the histone H4K5acK8ac (res 1-10) peptide with the strongest affinity $\left(\mathrm{K}_{\mathrm{D}}=28.1 \pm 1.6 \mu \mathrm{M}\right)$ [17]. Listed from strongest to weakest binding, the ATAD2B bromodomain is able to recognize H4K5acK8ac (1-10), H4K5ac (1-10), H2AK5ac (1-12), H4K5acK12ac (1-15), H4K12ac (4-17), H4K12acK16ac (10-20), H4K12ac (1-15) and H4K8ac (1-10). The H4K8ac (110) ligand binds to the ATAD2B bromodomain very weakly $\left(\mathrm{K}_{\mathrm{D}}=1164.2 \pm 28.5 \mu \mathrm{M}\right)$ by ITC (Fig. 2C), but this interaction was confirmed by NMR chemical shift perturbation experiments (Fig. 3A). The ATAD2B bromodomain appears to use a large reading frame to interpret the histone code since specific coordination of the histone $\mathrm{H} 4 \mathrm{~K} 5 \mathrm{acK} 12 \mathrm{ac}$ peptide spans a section of at least nine amino acid residues. Also, recognition of acetylation modifications at position 5 and 8 on the histone $\mathrm{H} 4$ tail is significantly altered by removal of the first three residues of the histone tail (compare Fig. 2B-C with Fig. 2M-N). Together our data show that the ATAD2B bromodomain preferentially selects for the di-acetylated histone ligand $\mathrm{H} 4 \mathrm{~K} 5 \mathrm{acK} 8 \mathrm{ac}$, and has the ability to read epigenetic signaling information from an 8-10 residue region on the $\mathrm{N}$-terminal histone tails.

\section{Mapping of the ATAD2B bromodomain binding pocket}

The X-ray crystal structure of the apo ATAD2B bromodomain has been solved (PDB: 3LXJ), but there are no data available on the molecular mechanism of histone recognition. To obtain specific information on how the ATAD2B bromodomain recognizes histone ligands at the molecular level we first completed 
bioRxiv preprint doi: https://doi.org/10.1101/263624; this version posted February 11,2018 . The copyright holder for this preprint (which was not certified by peer review) is the author/funder, who has granted bioRxiv a license to display the preprint in perpetuity. It is made available under aCC-BY-NC-ND 4.0 International license.

Recognition of acetyllysine by the ATAD2B bromodomain

the NMR backbone assignment of the ${ }^{15} \mathrm{~N},{ }^{13} \mathrm{C}$-labeled ATAD2B bromodomain (Fig. 3B). Then, we mapped the acetyllysine binding pocket by plotting the NMR chemical shift perturbations observed in the ${ }^{1} \mathrm{H}-{ }^{15} \mathrm{~N}$ HSQC NMR spectra upon addition of mono- and di-acetylated histone ligands, including H4K5ac (1-10), H4K8ac (1-10), H4K5acK8ac (1-10), H4K5ac (1-15) and H4K5acK12ac (1-15) (Fig. 4).

Chemical shifts are a powerful way to probe protein-ligand binding interactions due to the high sensitivity of this method over a broad affinity range, and the ability to link chemical shift changes to specific amino acid residues. Chemical shift perturbations occur due to changes in the magnetic environment of the amino acid residue that may occur due to a direct interaction of the residue with the ligand, a conformational change in the residue(s), or neighboring residue(s) [28]. The NMR chemical shifts were normalized in parts per million (ppm) across all histone ligands and then plotted in bar graphs to identify residues whose signals moved the most with the addition of each histone ligand. Chemical shift perturbations greater than $0.4 \mathrm{ppm}$ are shown in red and indicate the most movement, while shifts greater than $0.3 \mathrm{ppm}$ are shown in orange, and shifts greater than $0.2 \mathrm{ppm}$ are shown in yellow (Fig. 4). Six residues in the ATAD2B bromodomain consistently demonstrated chemical shift changes greater than 0.4 ppm upon addition of the histone ligands. Residues Val 987, Tyr 1007, Asn 1038, Asp 1042, Asp 1045, and Arg 1051 were large movers with the majority of the histone ligands tested. Two regions of the ATAD2B bromodomain backbone are involved in most of the chemical shift perturbations observed upon addition of the histone ligands. These regions span residues 976-1007 and 1031-1056, which are highlighted in green and magenta, respectively, in Figure 4F. This area significantly overlaps the variable ZA and BC loop regions that include residues 977-1004 and 1037-1042, respectively, although we observe significant chemical shift changes in the $\alpha \mathrm{B}$ and $\alpha \mathrm{C}$ helices on either side of the $\mathrm{BC}$ loop (magenta coloring in Fig. 4F). Thus, our data indicate that significant chemical shift perturbations are induced in the ZA and BC loops of the ATAD2B bromodomain upon ligand binding. Previously, large conformational changes were observed in these regions of the ATAD2 bromodomain structure reported by Poncet-Montange, et al., 2015 [15]. Our NMR data show that larger chemical shift perturbations occur in the $\mathrm{BC}$ loop than in the ZA loop region in the ATAD2B bromodomain. Also of note is that many of the conserved residues involved in ligand coordination for the ATAD2 bromodomain, such as the RVF shelf residues (ATAD2 1007-1009, ATAD2B 981-983) and gatekeeper residue (Ile 1074/Ile 1048), do not demonstrate significant (above $0.2 \mathrm{ppm}$ ) chemical shift perturbations upon ligand binding. Residues that are likely to be involved directly in histone ligand coordination and show large chemical shifts in the ATAD2B bromodomain include the universally conserved asparagine, Asn 1038, which coordinates the acetyllysine moiety, and Val 987, which lines the hydrophobic binding pocket. From these data we hypothesize that acetyllysine ligand recognition is initiated by structural changes in the flexible loop regions that recruit the histone ligands to the bromodomain binding pocket, resulting in specific hydrogen bond and hydrophobic interactions that occur upon ligand docking.

The observed chemical shift perturbations were mapped onto the surface of the apo ATAD2B bromodomain X-ray crystal structure (PDBID: 3LXJ [10]) to further outline the acetyllysine binding pocket, and to infer differences between coordination of mono- versus di-acetylated histone ligands. The most notable difference in the chemical shift perturbation patterns includes an induced shift in residue Arg 979, which only occurs with addition of the H4K5acK8ac and H4K5acK12ac histone ligands. Thus, it is likely that amino acids in this region are involved in coordinating the second acetylation group. However, since it is quite possible that the formation of specific hydrogen bond and hydrophobic contacts with di-acetylated histone ligands do not result directly in changes in the chemical shift perturbation pattern, further investigation is still required to determine the specific molecular interactions driving diacetyllysine recognition.

\section{Bromodomain binding pocket residues important for histone ligand recognition}

As mentioned above specific residues showed large chemical shift perturbations upon histone ligand binding. To elucidate the role of individual amino acids we used site directed mutagenesis coupled to ITC 
bioRxiv preprint doi: https://doi.org/10.1101/263624; this version posted February 11,2018 . The copyright holder for this preprint (which was not certified by peer review) is the author/funder, who has granted bioRxiv a license to display the preprint in perpetuity. It is made available under aCC-BY-NC-ND 4.0 International license.

Recognition of acetyllysine by the ATAD2B bromodomain

binding assays to confirm the importance of these residues in histone recognition. We introduced three different mutations into the ATAD2B bromodomain: Y995A, Y1037A and N1038A. Each mutation was chosen based on its predicted role in the binding pocket. For example Tyr 995, which correlates to Tyr 1021 in ATAD2, coordinates the histone ligand via a water-mediated hydrogen bond [29]. Tyr 1037 corresponds to Tyr 1063 in the ATAD2 bromodomain, which forms one side of the acetyllysine binding pocket and creates hydrophobic contacts to the lysine side chain. Tyr 1063 also forms a hydrogen bond to the peptide backbone on the N-terminus of the histone ligand. Lastly, Asn 1038 is the universally conserved asparagine residue found in nearly all bromodomain binding pockets, including the ATAD2/B bromodomains [30]. The locations of each of these mutations are mapped onto the ATAD2B bromodomain binding pocket in Figure 5A. We tested the effect of each of these mutations on histone ligand recognition with the H2AK5ac (1-12), H4K5ac (1-10), H4K12ac (4-17) and H4K5acK8ac (1-10) peptides, as well as histone H4 unmodified (4-17) as a control (Table 2 and Supplemental Fig. 1). Mutation of residues Tyr 995 and Tyr 1037 to alanine resulted in no binding to the mono- or di-acetylated histone ligands. Surprisingly however, the ATAD2B N1038A mutant still showed very weak binding activity for the $\mathrm{H} 2 \mathrm{AK} 5 \mathrm{ac}, \mathrm{H} 4 \mathrm{~K} 5 \mathrm{ac}$, and $\mathrm{H} 4 \mathrm{~K} 5 \mathrm{acK} 8 \mathrm{ac}$ histone ligands with $\mathrm{K}_{\mathrm{D}} \mathrm{s}$ of $1697.0 \pm 524.0 \mu \mathrm{M}$, $1153.3 \pm 170.0 \mu \mathrm{M}$, and 1429.2 $\pm 172.0 \mu \mathrm{M}$, respectively (Table 2). To verify that the loss of histone ligand binding was not due to protein misfolding after the insertion of the mutation, we used circular dichroism (CD) to analyze the secondary structures of all of the ATAD2B mutants (Fig. 5B). As seen in Table 3 and Figure 5B, the three ATAD2B mutant bromodomain proteins maintained alpha helical content similar to the wild-type ATAD2B bromodomain. Taken together, our data indicate that residues Tyr 995 and Tyr 1037 are crucial for histone ligand coordination and binding, while residue Asn 1038 also plays an important role, but possibly to a lesser extent.

\section{Recognition of the ATAD2 bromodomain inhibitor compound 38}

The search for potent ATAD2 bromodomain inhibitors has been an intense area of research because the overexpression of ATAD2 is strongly correlated with cancer progression [31-33]. In 2015 PoncetMontange et al., [15] identified dimethylisoxazole-containing ligands as the first ATAD2 binders, followed by the discovery and optimization of naphthyridones into the first potent ATAD2 bromodomain inhibitors with nanomolar binding affinity $[15,25]$. In these studies, compound 38 (C-38) was developed as the first small molecule possessing significant binding selectivity for the ATAD2 bromodomain over the BRD4 BD1 bromodomain in the BET bromodomain subfamily [25]. C-38 demonstrated a binding $\mathrm{K}_{\mathrm{D}}$ for the ATAD2 bromodomain of $90 \mathrm{nM}$ by surface plasmon resonance assays; however, the BROMOscan panel revealed that the closely related compound 46 (with a better permeability profile) had strong activity against the ATAD2B bromodomain and the second bromodomains of TAF1 and TAF1L [25]. C38 was synthesized and provided to us by our collaborator Dr. James Bradner. We tested the activity of C38 against the ATAD2B bromodomain by ITC and confirmed that this ATAD2 bromodomain inhibitor also interacts with the ATAD2B bromodomain in the nanomolar range with a $K_{\mathrm{D}}$ of $160.6 \pm 12.3 \mathrm{nM}$ (Table 1). In comparison, C-38 was shown to bind to the ATAD2 bromodomain with a $K_{\mathrm{D}}$ of $90 \mathrm{nM}$ [25].

Since the binding affinity of the ATAD2B bromodomain for C-38 is almost 2-fold lower than the ATAD2 bromodomain [25], we solved the X-ray structure of this compound in complex with the ATAD2B bromodomain to investigate the molecular details of the inhibitor interaction (Table 4 and Figure 6). As seen in Figure 6A and 6C, the ATAD2B bromodomain coordinates C-38 through a combination of hydrogen bonds and hydrophobic interactions. The guanidinium group of Arg 1051 makes specific hydrogen bond contacts to the sulfone oxygen atoms of ring E in C-38, while the OD1 carboxyl group of Asp 1045 contacts the piperdine nitrogen in ring D. The universally conserved Asn 1038 makes a number of hydrogen bonds to C-38. Asn 1038 binds the exocyclic amino group between the $\mathrm{D}$ and $\mathrm{B}$ rings, and forms $\mathrm{H}$-bonds with both the nitrogen and oxygen atoms in the lactam ring $\mathrm{C}$. The hydroxyl group of Tyr 995 also coordinates the oxygen atom of the lactam ring $\mathrm{C}$ through an ordered water molecule. Lastly, the backbone nitrogen of Asp 988 makes an H-bond contact with the nitrogen 
bioRxiv preprint doi: https://doi.org/10.1101/263624; this version posted February 11,2018 . The copyright holder for this preprint (which was not certified by peer review) is the author/funder, who has granted bioRxiv a license to display the preprint in perpetuity. It is made available under aCC-BY-NC-ND 4.0 International license.

Recognition of acetyllysine by the ATAD2B bromodomain

atom of pyridine ring A in C-38. Weaker electron density was observed for ring E near C16 and ring D near $\mathrm{C} 10$ in C-38 than for compound C-42 with the ATAD2 bromodomain [25], which is likely related to the lower affinity for C-38 by the ATAD2B bromodomain. Electron density was observed for the sulfone group in coordination with Arg 1051 and for the piperdine nitrogen, which is oriented to interact with Asp 1045.

Important hydrophobic interactions occur between C-38 and the side chains of the gatekeeper residue Ile 1048 and Ile 982 in the NIF shelf in the ATAD2B bromodomain (RVF shelf in ATAD2). Val 992 and Tyr 1037 also contribute to the hydrophobic coordination of C-38 by forming part of the ATAD2B bromodomain binding pocket wall. The conserved Asn 1038 seems to play a large role, especially deeper in the binding pocket, and is likely the driving force maneuvering the inhibitor into the bromodomain binding pocket in a favorable alignment. Notably, many of the residues that are involved in coordination of the C-38 inhibitor also make conserved contacts to the acetylated histone ligands as demonstrated by our NMR chemical shift perturbation and mutagenesis experiments (Fig. 4 and Table 2). Thus, further optimization of new inhibitors to take better advantage of the small differences between the ATAD2/B bromodomains will be necessary to improve the binding specificity of new therapeutic compounds. Overall the ATAD2/B bromodomain acetyllysine binding pockets are very highly conserved, and finding inhibitors that will differentiate between these two bromodomains will be challenging. However, one region with significant differences between the ATAD2/B bromodomains is at the RVF shelf motif found in ATAD2 (residues Arg 1007, Val 1008 and Phe 1009), which forms an NIF shelf in the ATAD2B bromodomain (residues Asn 981, Ile 982 and Phe 983) (Fig 6A and 6B). Thus, this area of the bromodomain binding pockets may provide an opportunity for enhancing inhibitor interactions.

DISCUSSION: This study is the first to describe the histone ligands recognized by the ATAD2B bromodomain. We determined that the ATAD2B bromodomain is a di-acetyllysine reader domain that preferentially binds to histone $\mathrm{H} 4 \mathrm{~K} 5 \mathrm{acK} 8 \mathrm{ac}$ with a $\mathrm{K}_{\mathrm{D}}$ of $28.1 \pm 1.6 \mu \mathrm{M}$. We also found that the ATAD2B bromodomain is able to recognize the di-acetylated histone ligands H4K5acK12ac and H4K12acK16ac with weaker affinity, as well as a number of mono-acetylated histone ligands including H2AK5ac, H4K5ac, H4K12ac and H4K8ac. Importantly, the binding affinities derived from our ITC experiments are well within the affinity ranges previously reported for other closely related bromodomains in subfamily IV [13, 15-17]. NMR titration experiments confirmed the interaction of the ATAD2B bromodomain with the mono- and di-acetylated histone ligands. We also compared the chemical shift perturbations observed in the NMR ${ }^{15} \mathrm{~N}-{ }^{1} \mathrm{H}-\mathrm{HSQC}$ spectra to outline the ATAD2B bromodomain acetyllysine binding pocket, and identify amino acid residues that are important for ligand coordination. Site-directed mutagenesis studies coupled to ITC experiments confirmed the importance of the universally conserved asparagine residue Asn 1038, as well as two tyrosine residues that comprise part of the acetyllysine binding pocket wall, as mutation of these residues to alanine dramatically reduce or completely inhibit binding of the H2AK5ac, H4K5ac, H4K12ac and H4K5acK8ac ligands.

Surprisingly, we only observed one difference in the ATAD2B chemical perturbation maps when comparing recognition of the mono and di-acetylated histone ligands. The chemical shifts seen with residue Arg 979 upon addition of the H4K5acK8ac and H4K5acK12ac ligands suggests that this residue, which is located distal to the canonical bromodomain binding pocket, may play an important role in recognition of larger regions of the histone $\mathrm{H} 4$ tail. Lastly, we solved the structure of the ATAD2B bromodomain with an ATAD2 bromodomain inhibitor, and identified molecular contacts that are important for inhibitor coordination. Collectively, these studies allowed us to elucidate differences in the bromodomain binding pockets for the closely related ATAD2/B paralogs that can potentially be utilized to improve the selectivity of future bromodomain inhibitors. Our experimental evidence indicates that although the ATAD2/B bromodomains are highly conserved, they do exhibit different histone ligand binding activities, and likely play different roles in the cell.

Prior to this study, Leachman et al., 2010 [1] published one of the only sources of information on the 
bioRxiv preprint doi: https://doi.org/10.1101/263624; this version posted February 11,2018 . The copyright holder for this preprint (which was not certified by peer review) is the author/funder, who has granted bioRxiv a license to display the preprint in perpetuity. It is made available under aCC-BY-NC-ND 4.0 International license.

Recognition of acetyllysine by the ATAD2B bromodomain

ATAD2B protein. They studied the expression of ATAD2B in chicken embryos and human tumors with a polyclonal antibody raised against a fragment of the human ATAD2B recombinant protein. ATAD2B was found transiently expressed during the development of neuronal cells, and was also found in glioblastoma, oligodendroglioma and human breast carcinoma [1]. In 2012, the X-ray crystal structure of the ATAD2B (KIAA1240) bromodomain was deposited as an apo structure in the Protein Data Bank (PDBID: 3LXJ) as part of a large-scale structural analysis of human bromodomains [10]. In the SPOT peptide array, ATAD2B demonstrated very strong interactions with acetylated histone peptides H2AK36ac, H2BK43ac, H2BK85ac, H3K56ac, H4K5ac, and H4K59ac [10]. It is clear from our experience determining the histone ligands of the BRPF1 bromodomain that high-throughput methods are important for identifying potential ligands, but more traditional biochemical and biophysical methods are necessary to validate the interactions and measure the binding affinities [13]. It is not certain if acetylated lysine found outside of the N-terminal histone tail region (usually defined as the first 30 amino acid residues) would be sterically available for bromodomain recognition since they are located in the globular core domain of the histone proteins. Unfortunately, more specific follow up assays were not performed on the ATAD2B bromodomain to confirm these interactions.

However, the ATAD2 bromodomain, which is $74.7 \%$ identical and $94.4 \%$ similar to the ATAD2B bromodomain, has been studied much more extensively due to its association with the development of multiple human cancers. X-ray crystal structures of the ATAD2 bromodomain in complex with the H4K5ac and H4K12ac histone ligands have been solved [15, 16], and the ATAD2 bromodomain binds to the H4K5ac (1-20) with an affinity of $22 \mu \mathrm{M}$ as measured by ITC [15]. Poncet-Montange et al., 2015 [15] also used an AlphaScreen assay to identify other potential ligands for the ATAD2 bromodomain and observed interactions with the H4K12ac peptide in addition to the H4K5ac ligand [15]. More recently Koo et al., 2016 [17] tested the interaction of the GST-tagged wild-type ATAD2 bromodomain with various histone peptide ligands using TR-FRET (Time-Resolved Fluorescence Energy Transfer) [17]. This assay demonstrated that the strongest interactions of the ATAD2 bromodomain occurred with the H4K12ac (1-15), H4K5acK12ac (1-25), H4K5ac (1-25), H4K5acK8acK12acK16ac (1-25), and H4K8ac (1-25) histone peptides. They measured the dissociation constant of the ATAD2-H4K12ac interaction to be $3.3 \pm 0.2 \mu \mathrm{M}$ by microscale thermophoresis (MST), $2.5 \mu \mathrm{M}$ by ITC and $7.9 \pm 1.5 \mu \mathrm{M}$ by surface plasmon resonance (SPR) [17]. NMR chemical shift perturbation experiments carried out in the presence of the H4K12ac (1-25) ligand indicate that, consistent with our data, a large number of residues in the acetyllysine binding pocket of the ATAD2 bromodomain shift upon peptide binding [17]. However, the specific residues involved were not labeled, and there is no binding affinity data reported for the interaction of the di-acetylated H4K5acK12ac ligand with the ATAD2 bromodomain. Thus, although recognition of the di-acetylated $\mathrm{H} 4 \mathrm{~K} 5 \mathrm{acK} 12 \mathrm{ac}$ ligand was shown to be important for the biological function of the ATAD2 bromodomain on newly synthesized histones during DNA replication, this ligand does not appear to be the strongest binding acetylated histone ligand for ATAD2 as observed in the TRFRET assay [17]. The interaction of the ATAD2 bromodomain with an H4K5acK8ac histone ligand was not tested. However, the previous studies carried out on the ATAD2 bromodomain are in-line with our observed results for the histone binding partners of the ATAD2B bromodomain, and together our data indicate that the ATAD2/B bromodomains possess slightly different histone binding specificities despite being highly conserved paralogs.

Flexibility of the bromodomain reader module is a key factor in the selection and recruitment of histone ligands. Using a molecular dynamics (MD) approach Langini et al., 2017 [34] simulated the ATAD2 bromodomain binding trajectories of the H4K5acK12ac (1-16) ligand with either a buried K5ac, K12ac, or just the bromodomain in the apo state [34]. Their models showed that the ATAD2 bromodomain module is mostly rigid in its apo and holo states, but the binding interface appears to remain in a partially disordered state [34]. They observed that the ZA loop of ATAD2 bromodomain (res 1003-1030) is a major site of disorder, as well as expanded region around the BC loop, which includes residues 1056-1074 [34]. Addition of histone ligands to the ATAD2B bromodomain in our NMR 
bioRxiv preprint doi: https://doi.org/10.1101/263624; this version posted February 11,2018 . The copyright holder for this preprint (which was not certified by peer review) is the author/funder, who has granted bioRxiv a license to display the preprint in perpetuity. It is made available under aCC-BY-NC-ND 4.0 International license.

Recognition of acetyllysine by the ATAD2B bromodomain

chemical shift experiments induced chemical shift perturbations in the ZA loop of ATAD2B bromodomain (res 977-1004), but the BC loop residues (1031-1055) displayed even larger chemical shifts (Fig. 4), which suggests either direct ligand interactions or conformational changes are occurring in this region. Interestingly, our previous NMR studies on the BRPF1 bromodomain showed a similar magnitude of chemical shifts in both the ZA and BC loop regions [13]. Thus, inherent mobility in the ZA and BC loop regions could be a common feature of the bromodomain binding pockets, and they may retain unordered properties even when a ligand is bound. The MD simulations of the ATAD2 bromodomain also detected molecular contacts between the histone ligand and a patch of negatively charged residues on the ZA loop. These residues included Glu 1017 and Asp 1020, which correspond to residues Glu 991 and Asp 994 in the ATAD2B bromodomain. As seen in Figure 4, Glu 991 shows a significant chemical shift upon addition of nearly all histone ligands tested. Glu 991 corresponds to residue Asp 36 in the BRPF1 bromodomain, which also demonstrated one of the largest chemical shift perturbations upon ligand binding [13]. Mutation of Asp 36 to alanine in the BRPF1 bromodomain resulted in a modest reduction in the binding activity for the H4K12 and H2AK5ac histone ligands, reducing the affinity from $48 \mu \mathrm{M}$ to 89 $\mu \mathrm{M}$ (1.9-fold), and $77 \mu \mathrm{M}$ to $205 \mu \mathrm{M}$ (2.6-fold), respectively, when compared to the wild-type protein [14]. Thus, this residue appears to interact as a peripheral contact to the acetylated histone ligands, and it may play an important role in the initial recruitment of the acetylated ligand into the bromodomain binding pocket. Overall, our data supports the suggestion by Langini et al., 2017 [34] that dynamic motions in the binding pocket loops are likely important for the initial selection of the histone ligand, while ligand specificity is conferred by conserved amino acids that do not demonstrate large conformational changes upon ligand binding [34]. Thus, flexibility in the ZA and BC loop regions allow for rapid on/off rates of the histone ligand, and cooperative coordination of adjacent acetyllysine marks, but the universally conserved asparagine, the gatekeeper, and the NIF/RVF shelf motif residues in the ATAD2/B bromodomains drive histone ligand recognition at the molecular level.

Our ITC binding data on the interaction of the ATAD2B bromodomain with the GlaxoSmithKline ATAD2 bromodomain inhibitor C-38 (Fig. 2P) is in-line with the previously published observation that $\mathrm{C}-38$ binds well to both the ATAD2/B bromodomains in the nanomolar range [25]. The X-ray crystal structure of the ATAD2B bromodomain in complex with C-38 (PDBID: 6BSO) is highly conserved with the structure of the ATAD2 bromodomain in complex with the bromodomain inhibitor compound 42 (C42, PDBID: 5A83). C-42 was also developed by GlaxoSmithKline as a derivative of C-38 with increased cell membrane permeability [25]. C-38 differs from C-42 only by the presence of one nitrogen atom in the lactam ring $\mathrm{B}$, which is a carbon in $\mathrm{C}-42$. The coordination of $\mathrm{C}-42$ in the ATAD2 bromodomain is nearly identical to the coordination of C-38 by the ATAD2B bromodomain (compare Fig. 6A-B and Fig. 6C-D, and see Supplemental Fig. 2). The hydrogen bonding pattern of the ATAD2/B bromodomains with these two bromodomain inhibitors is completely conserved with important $\mathrm{H}$-bonds formed to the universally conserved asparagine Asn 1038 and Asn 1064 in the ATAD2/B bromodomains, respectively. In the ATAD2-C-42 structure there are also H-bonds to the backbone nitrogen of Asp 1014, and the side chains of Asp 1071 and Arg 1077. The only apparent difference between the two bromodomain proteins in the coordination of these inhibitor molecules occurs through an increased hydrophobic contact between Val 1008 in the RVF shelf motif of the ATAD2 bromodomain and the lactam ring B caused by replacing the nitrogen in C-38 with carbon in C-42. The RVF shelf motif in the ATAD2 bromodomain is also the only region in the acetyllysine binding pocket that differs between the ATAD2/B bromodomains, which is an NIF shelf motif in ATAD2B. The highly conserved nature of the ATAD2/B bromodomain paralog poses a challenge to develop inhibitor molecules that will selectively inhibit one of these two bromodomains and not also retain activity toward the other. This is a particularly important problem to solve considering the differences in the biological roles of the ATAD2/B bromodomains, and the prominent involvement of ATAD2 in cancer progression. Surprisingly, a recent inhibitor discovered by Bayer Pharmaceuticals (BAY-850) exclusively hit the ATAD2 bromodomain, but not the ATAD2B bromodomain in the BROMOscan panel [27]. This breakthrough discovery of 'unprecedented isoform selectivity' towards the 
bioRxiv preprint doi: https://doi.org/10.1101/263624; this version posted February 11,2018 . The copyright holder for this preprint (which was not certified by peer review) is the author/funder, who has granted bioRxiv a license to display the preprint in perpetuity. It is made available under aCC-BY-NC-ND 4.0 International license.

Recognition of acetyllysine by the ATAD2B bromodomain

ATAD2 bromodomain was also confirmed by thermal shift assays and ITC. Interestingly, binding of BAY-850 to the ATAD2 bromodomain induces dimerization of two bromodomain modules, which then prevents their interaction with acetylated histone peptide ligands [27]. It will be particularly interesting to see the molecular details of the BAY-850 ligand interaction with the ATAD2 bromodomain. Hopefully, this information will provide some insight on how to also specifically target the ATAD2B bromodomain in the future. Our data suggests that the NIF shelf motif in the ATAD2B bromodomain may be an important region to focus on, unless there is a unique site in the ATAD2B bromodomain that could also be targeted to induce dimerization to prevent histone interactions.

Collectively, the results from this study describe the histone ligands of the ATAD2B bromodomain, and outline many important features of the bromodomain binding pocket that contribute to ligand selection and specificity. This information will be valuable for the development of selective ATAD2B bromodomain inhibitors or tool compounds that can be used to further investigate the biological function of the ATAD2B protein, which has yet to be elucidated. We discovered that the ATAD2B bromodomain is a di-acetyllysine reader module, however the significance of histone H4K5acK8ac ligand binding has yet to be determined. Linking the recognition of histone H4K5acK8ac to particular cellular outcomes will be essential for understanding the unique role of the ATAD2B bromodomain, and how it functions differently from the ATAD2 protein. Our NMR chemical shift perturbation experiments identified one amino acid residue that differed between coordination of mono- and di-acetylated histone ligands. Thus, it will be essential to solve the structure of the ATAD2B bromodomain with di-acetylated histones in order to discover the molecular details of the binding mechanism. However, our results demonstrate that although the ATAD2/B bromodomain modules are highly conserved paralogs, they preferentially recognize different subsets of acetylated histone ligands, which suggests they are involved in divergent biological pathways.

It is important to note that while the ITC and NMR experiments were robust, the X-ray crystal structure of the ATAD2B bromodomain in complex with C-38 was derived from a molecular replacement solution using the ATAD2B bromodomain, and the structure of the C-38 compound was built from the initial configuration of C-42 in complex with the ATAD2 bromodomain. The overall resolution of our structural model of the ATAD2B-C-38 complex was lower than that observed for the ATAD2 bromodomain in complex with $\mathrm{C}-42$, thus the density observed for C-38 was less robust, although it did provide an unambiguous view of the inhibitor conformation in the binding pocket. We were still able to observe many of the same characteristic features involved in the coordination of C-38 by the ATAD2B bromodomain that were observed in the ATAD2 coordination of $\mathrm{C}-42$, which provide an additional level of confidence in our structural model of this interaction. Also, while our biochemical and biophysical analysis provides a clear characterization of the histone ligands preferentially selected for by the ATAD2B bromodomain, this information may not be directly translated to the cell, where in vivo the abundance of the H4K5acK8ac ligand may be relatively small compared to either the H4K5ac or H4K12ac ligands, which also bind strongly to the ATAD2B bromodomain. Thus, further experimentation will be necessary to fully appreciate the biological significance of these interactions.

In conclusion, we describe here the novel histone binding specificity of the ATAD2B bromodomain. Our study outlines the important residues involved in mono- and di-acetylated histone ligand recognition, as well as in coordination of the small molecule bromodomain inhibitor C-38. These data provide insight into how they may be specifically inhibited to further advance our understanding of differences in the roles of the ATAD2/B bromodomains in normal biological processes and in the development of disease.

\section{EXPERIMENTAL PROCEEDURES: Plasmid Construction:}

Human ATAD2B (UniProt code Q9ULIO) cDNA was generously provided by AddGene. The bromodomain region (residues 953-1085) was PCR-amplified and cloned into the pDEST15 vector encoding an N-terminus GST tag using the Gateway Cloning Technology (Invitrogen) [13]. ATAD2B 
bioRxiv preprint doi: https://doi.org/10.1101/263624; this version posted February 11,2018 . The copyright holder for this preprint (which was not certified by peer review) is the author/funder, who has granted bioRxiv a license to display the preprint in perpetuity. It is made available under aCC-BY-NC-ND 4.0 International license.

Recognition of acetyllysine by the ATAD2B bromodomain

bromodomain mutants N1038A, Y995A and Y1037A were generated using the QuikChange ${ }^{\circledR}$ mutagenesis procedure (Stratagene) [35]. The DNA sequence of each was verified (University of Vermont Cancer Center Advanced Genome Technologies Core) and then transformed into Escherichia coli Rosetta 2(DE3)pLysS competent cells (Novagen).

\section{Protein Expression and Purification:}

E. coli cells containing the GST-tagged ATAD2B wild-type or mutant bromodomain were grown in $4 \mathrm{~L}$ Terrific broth (TB) at $37^{\circ} \mathrm{C}$. The culture temperature was dropped to $20^{\circ} \mathrm{C}$ for 1 -hour when the $\mathrm{OD}_{600}$ reached 1 . The culture was then induced by the addition of $0.25 \mathrm{mM}$ isopropyl $\beta$-D-1thiogalactopyranoside (IPTG), and the cells were harvested by pelleting after $16 \mathrm{~h}$ of incubation at $20^{\circ} \mathrm{C}$

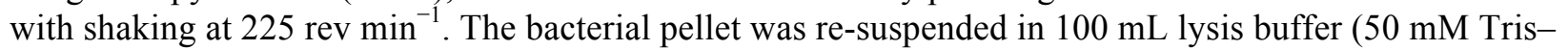
$\mathrm{HCl} \mathrm{pH} 7.5,150 \mathrm{mM} \mathrm{NaCl}, 0.05 \%$ Nonidet P-40, $1 \mathrm{mM}$ DTT) containing $1 \mathrm{~mL}$ lysozyme and the cells were lysed by sonication. The cell lysate was cleared by centrifugation (10,000 rev $\mathrm{min}^{-1}$ for $\left.20 \mathrm{~min}\right)$. The supernatant was added to $15 \mathrm{~mL}$ of glutathione agarose resin (which binds up to $40 \mathrm{mg}$ of purified recombinant GST protein per milliliter of resin) (Thermo Scientific) and incubated on ice $\left(4^{\circ} \mathrm{C}\right)$ while agitating for 120 minutes. After incubation, the suspension was centrifuged for $5 \mathrm{~min}$ at $500 \mathrm{x}$ g to collect the beads. The collected beads were poured into a $25 \mathrm{~mL}$ Econo-Column Chromatography Column (Bio$\mathrm{Rad})$ and washed with four column volumes of wash buffer $(20 \mathrm{mM}$ Tris- $\mathrm{HCl} \mathrm{pH}$ 8.0, $150 \mathrm{mM} \mathrm{NaCl}, 1$ mM DTT). The GST tag was cleaved overnight at $4{ }^{\circ} \mathrm{C}$ by the addition of PreScission Protease $(\sim 100 \mu \mathrm{L}$ at $76 \mathrm{mg} / \mathrm{mL}$ ) (GE Healthcare) and the eluted ATAD2B bromodomain protein was concentrated to a total volume of approximately $3 \mathrm{~mL}$. For Isothermal Titration Calorimetry (ITC) or circular dichroism (CD) experiments protein was concentrated and dialyzed into buffers consisting of $20 \mathrm{mM} \mathrm{NaH}_{2} \mathrm{PO}_{4} \mathrm{pH} 7.0$ and $150 \mathrm{mM} \mathrm{NaCl}$, or $50 \mathrm{mM} \mathrm{NaH}_{2} \mathrm{PO}_{4} \mathrm{pH} 7.0$ and $50 \mathrm{mM} \mathrm{NaCl}$, respectively. For X-ray crystallography the protein was further purified using fast-protein liquid chromatography on an AKTA Purifier UPC 10 (GE Healthcare) over a HiPrep 16/60 Sephacryl S-100 high resolution gel filtration column (GE Healthcare) equilibrated with crystallography buffer (25 mM HEPES pH 7.5, $150 \mathrm{mM} \mathrm{NaCl}$ and $1 \mathrm{mM}$ DTT). Eluted fractions corresponding to the ATAD2B bromodomain were pooled and concentrated to 30 $\mathrm{mg} \mathrm{mL} \mathrm{m}^{-1}$ at $4^{\circ} \mathrm{C}$. The protein concentration was determined using the Pierce BCA Protein Assay Kit (Thermo Scientific) and was calculated from the absorption at $550 \mathrm{~nm}$ and the ATAD2B bromodomain extinction coefficient of $4470 \mathrm{M}^{-1} \mathrm{~cm}^{-1}$. The purity of the ATAD2B bromodomain was verified by SDSPAGE gels stained with GelCode Blue Safe protein stain (Thermo Scientific).

\section{Histone Peptide and Bromodomain Inhibitor Synthesis:}

Histone peptides were synthesized by the Peptide Core Facility at the University of Colorado Denver as unmodified histones, or designed to contain a specific acetyllysine modification(s). Each peptide has a free N-terminus and an amidated C-terminus. The peptides, supplied as the TFA salt, were purified to greater than $98 \%$ pure via HPLC, and their chemical identities were confirmed by mass spectroscopy before use. Sequence information for each of the peptides used in this study is shown in Table 1.

Compound 38 (C-38) is a potent ATAD2 bromodomain inhibitor developed by GlaxoSmithKline in 2015 [25]. C-38 was synthesized for us by Jay Bradner's laboratory according to the previously published procedure and isolated as the TFA salt [25].

\section{Isothermal Titration Calorimetry:}

ITC experiments were carried out at $5^{\circ} \mathrm{C}$ with a MicroCal ITC200 instrument (GE Healthcare). Each of the ATAD2B bromodomain proteins and histone peptide samples were dialyzed into a $\mathrm{NaPO}_{4}(\mathrm{pH} 7.0)$ and $150 \mathrm{mM} \mathrm{NaCl}$ buffer. Calorimetric titration was performed by titrating each histone tail ligand ( 5 $\mathrm{mM}$ ) into $0.2 \mathrm{mM}$ of the ATAD2B bromodomain protein in the sample cell in a series of 19 individual injections of $2 \mu \mathrm{L}$, at time intervals of 150 seconds. These were preceded by a preliminary injection of 0.5 $\mu \mathrm{L}$ of the $5 \mathrm{mM}$ peptide sample, which was excluded from the data integration and calculation of $\mathrm{K}_{\mathrm{D}} \mathrm{s}$. To 
bioRxiv preprint doi: https://doi.org/10.1101/263624; this version posted February 11,2018 . The copyright holder for this preprint (which was not certified by peer review) is the author/funder, who has granted bioRxiv a license to display the preprint in perpetuity. It is made available under aCC-BY-NC-ND 4.0 International license.

Recognition of acetyllysine by the ATAD2B bromodomain

determine the heat of dilution of the titrant peptides in the experimental buffer, control experiments were conducted under identical conditions. As part of data analysis, this was deducted from the experimental data. The obtained change-in-heat peaks were then analyzed by the Origin 7.0 program (OriginLab Corporation) and used to calculate binding affinities. Experiments in which binding occurred were performed in triplicate, while non-binding experiments were performed in duplicate.

\section{NMR Spectroscopy:}

Chemical shift perturbation experiments were conducted using uniformly ${ }^{15} \mathrm{~N}$-labeled ATAD2B bromodomain prepared at $0.500 \mathrm{mM}$ in buffer containing $20 \mathrm{mM}$ Tris- $\mathrm{HCl} \mathrm{pH}$ 6.8, $150 \mathrm{mM} \mathrm{NaCl}, 10$ mM DTT and $10 \% \mathrm{D}_{2} \mathrm{O} .35 \mu \mathrm{L}$ titration mixtures of the protein and peptide were made at concentration ratios of 1:0, 1:0.25, 1:0.5, 1:1.1, 1:2.5, and 1:5 for the unlabeled histone tail peptides containing specific acetyllysine modifications. 2D ${ }^{15} \mathrm{~N}$ HSQC (heteronuclear single quantum coherence) experiments for all samples were run at $25^{\circ} \mathrm{C}$ on a $600 \mathrm{MHz}$ Bruker AVANCE III spectrometer equipped with a $z$-gradient $1.7 \mathrm{~mm}$ TCI probe at the National Magnetic Resonance Facility at Madison (NMRFAM). The NMR data were collected with ${ }^{1} \mathrm{H}$ and ${ }^{15} \mathrm{~N}$ radio-frequency pulses applied at 4.745 parts per million (ppm) and 116 ppm, respectively. $1024 \times 128$ complex data points with spectral widths of $16 \mathrm{ppm}$ and $30 \mathrm{ppm}$, respectively, were collected along the ${ }^{1} \mathrm{H}$ and ${ }^{15} \mathrm{~N}$ dimensions, with 32 scans per FID and an inter-scan delay of $1.0 \mathrm{sec}$, resulting in a total experimental time of about $160 \mathrm{~min}$ for each HSQC spectrum. Transformed spectra at each titration point were overlaid and analyzed to characterize the relevant residues affected by the interaction between the ATAD2B bromodomain and the histone peptides. Normalized chemical shift changes were calculated using the equation:

$$
\Delta \delta=\sqrt{(\Delta \delta H)^{2}+(\Delta \delta N / 5)^{2}}
$$

where $\Delta \delta \mathrm{H}$ and $\Delta \delta \mathrm{N}$ are the proton and nitrogen change in chemical shift in ppm, respectively. The chemical shift values in ppm were normalized across all NMR HSQC spectra.

To obtain the backbone resonance assignments, the ${ }^{15} \mathrm{~N},{ }^{13} \mathrm{C}$ double labeled ATAD2B bromodomain was prepared at about $1 \mathrm{mM}$ in buffer containing $20 \mathrm{mM}$ Tris- $\mathrm{HCl} \mathrm{pH}$ 6.8, $150 \mathrm{mM} \mathrm{NaCl}, 10 \mathrm{mM}$ DTT and $10 \% \mathrm{D}_{2} \mathrm{O}$. The Bruker version of ADAPT-NMR (Assignment-directed Data collection Algorithm utilizing a Probabilistic Toolkit in NMR) was used to optimize simultaneous fast data collection and automated NMR assignment of the $\mathrm{HNCO}, \mathrm{HN}(\mathrm{CA}) \mathrm{CB}, \mathrm{HNCA}, \mathrm{HN}(\mathrm{CO}) \mathrm{CA}, \mathrm{HN}(\mathrm{CA}) \mathrm{CO}$, $\mathrm{CBCA}(\mathrm{CO}) \mathrm{NH}$, and $\mathrm{C}(\mathrm{CCO}) \mathrm{NH}$ spectra by achieving reduced dimensionality (2D) [36]. These experiments were run at $25{ }^{\circ} \mathrm{C}$ on a $600 \mathrm{MHz}$ Agilent INOVA spectrometer equipped with a $5 \mathrm{~mm} \mathrm{Z}$-axis pulsed field gradient triple resonance cold probe. The NMR data for all experiments were collected with the universal carrier position of ${ }^{1} \mathrm{H},{ }^{15} \mathrm{~N},{ }^{13} \mathrm{C}^{\mathrm{a}}$ (shaped pulse), ${ }^{13} \mathrm{C}^{\text {aliphatic }}\left({ }^{13} \mathrm{C}^{\mathrm{a} / \mathrm{b}}\right.$ or ${ }^{13} \mathrm{C}^{\mathrm{b}}$, shaped pulse),${ }^{13} \mathrm{C}^{\prime}$ (shaped pulse) applied at $4.76 \mathrm{ppm}\left(\mathrm{H}_{2} \mathrm{O}\right.$ frequency), $118 \mathrm{ppm}, 56 \mathrm{ppm}, 45 \mathrm{ppm}$, and $176 \mathrm{ppm}$ respectively. 1024, 32, 64, 64, and 64 complex data points with spectral widths of $16 \mathrm{ppm}, 36 \mathrm{ppm}, 32$ ppm, 70 ppm, and $22 \mathrm{ppm}$, respectively, were collected along the ${ }^{1} \mathrm{H},{ }^{15} \mathrm{~N},{ }^{13} \mathrm{C}^{\mathrm{a}},{ }^{13} \mathrm{C}^{\text {aliphatic }}$ and ${ }^{13} \mathrm{C}$ ' dimensions. Processing and analysis for all data was conducted automatically with ADAPT-NMR [36, 37]. After one day of the ADAPT-NMR run, an $84.7 \%$ assignment level was achieved. To generate visualized assignment labels on the $2 \mathrm{D}{ }^{1} \mathrm{H}-{ }^{15} \mathrm{~N}$ HSQC spectra, PINE-SPARKY and SPARKY were used $[38,39]$.

\section{Circular Dichroism Spectroscopy:}

Circular Dichroism (CD) spectra were recorded on a JASCO J-815 CD Spectrometer (JASCO, Japan) at $25^{\circ} \mathrm{C}$ in a $1.6 \mathrm{~cm}$ cell. ATAD2B bromodomain wild type (WT) or mutant proteins were dialyzed in 50 $\mathrm{mM} \mathrm{NaPO}_{4} \mathrm{pH}_{7.0}$ and $50 \mathrm{mM} \mathrm{NaCl}$ buffer and diluted to between $0.1 \mu \mathrm{M}$ and $0.5 \mu \mathrm{M}$ in concentration. CD spectra were measured from 199-260 nm. Two spectra were measured and averaged for each mutant bromodomain protein sample and the wild-type protein. Spectra were analyzed using the K2D3 structure prediction software to determine the percent $\alpha$-helical and $\beta$-sheet content [40]. 
bioRxiv preprint doi: https://doi.org/10.1101/263624; this version posted February 11,2018 . The copyright holder for this preprint (which was not certified by peer review) is the author/funder, who has granted bioRxiv a license to display the preprint in perpetuity. It is made available under aCC-BY-NC-ND 4.0 International license.

Recognition of acetyllysine by the ATAD2B bromodomain

\section{X-Ray Crystallography:}

The purified ATAD2B bromodomain protein at a concentration of $1.9 \mathrm{mM}$ was mixed with $1 \mathrm{mM}$ of C38 in a $1.5 \mathrm{~mL}$ microcentrifuge tube. Crystallization screens were set up using the sitting-drop method in 96-well VDX plates (Hampton Research), with drops consisting of $1 \mu \mathrm{L}$ protein-peptide mixture plus 1 $\mu \mathrm{L}$ reservoir solution and a reservoir volume of $100 \mu \mathrm{l}$. The ATAD2B bromodomain co-crystallized with the C-38 inhibitor in Index Screen condition No. 66 [0.2 M ammonium sulfate, 0.1 M Bis-Tris pH 5.5, $25 \%(\mathrm{w} / \mathrm{v})$ polyethylene glycol 3,350] at $4^{\circ} \mathrm{C}$. The C-38 crystals from Index Screen condition No. 66 were reproduced in hanging drops ( $1 \mu \mathrm{L}$ protein solution plus $1 \mu \mathrm{L}$ mother liquor) using 24 -well VDX plates (Hampton Research) containing $500 \mu \mathrm{L}$ mother liquor in the reservoir. The crystals were cryoprotected by adding $15 \%$ glycerol to the drop and immediately flash-cooled into liquid nitrogen at $100 \mathrm{~K}$ as described by Garman et al., 1999 [41]. Data for the C-38 crystals was collected at the Argonne National Laboratory Advanced Photon Source, GM/CA Sector 23, beamline 23IDD set to a wavelength of $1.033 \AA$ with a Pilatus $6 \mathrm{M}$ detector. The diffraction data were processed using the Proteum3 suite (Bruker). The structure was solved by molecular replacement using Phaser with the apo ATAD2B bromodomain structure (PDBID: 3LXJ) as the starting model [42]. The model was built using COOT to add the C-38 inhibitor, and PHENIX and COOT were used for iterative rounds of refinement, density modification and model building [43, 44]. The final structure at $2.2 \AA$ A resolution was validated using MolProbity and Polygon [45, 46].

ACKNOLWEDGEMENTS: We are especially thankful to Brian E. Eckenroth in the Department of Microbiology and Molecular Genetics at the University of Vermont for his assistance with crystallographic data collection, processing and analysis of the ATAD2B bromodomain structure in complex with C-38. We are very grateful to Dennis L. Buckley and James E. Bradner at the Dana-Farber Cancer Institute/Harvard Medical School in Boston, MA for re-synthesizing and sharing compound 38 with us for use in this study. This study was supported by a National Institute of Health grant, NIGMS 2R15GM104865-02 to KCG. JTL was the recipient of an ACPHS graduate research assistantship from 2016-2017. This study made use of the National Magnetic Resonance Facility at Madison, which is supported by NIH grant P41GM103399 (NIGMS). NMRFAM equipment was purchased with funds from the University of Wisconsin-Madison, the NIH P41GM103399, S10RR02781, S10RR08438, S10RR023438, S10RR025062, S10RR029220), the NSF (DMB-8415048, OIA-9977486, BIR-9214394), and the USDA. Crystal growth, screening and initial data collection was carried out at the Center for Xray Crystallography at the University of Vermont, which is supported by the National Institutes of Health Grants P01CA098993 and R01CA52040, awarded to Sylvie Doublié by the National Cancer Institute. We also thank Dr. Matthew Liptak and Amanda Roffman in the Department of Chemistry at the University of Vermont for their advice and assistance setting up circular dichroism spectroscopy experiments. DNA sequencing was performed in the University of Vermont Cancer Center Advanced Genome Technologies Core. The structure of the ATAD2B bromodomain in complex with compound 38 was deposited into the Protein Data Bank (PDBID: 6BSO). GM/CA@APS has been funded in whole or in part with Federal funds from the National Cancer Institute (ACB-12002) and the National Institute of General Medical Sciences (AGM-12006). This research used resources of the Advanced Photon Source, a U.S. Department of Energy (DOE) Office of Science User Facility operated for the DOE Office of Science by Argonne National Laboratory under Contract No. DE-AC02-06CH11357.

CONFLICT OF INTEREST: The authors declare that they have no conflicts of interest with the contents of this article.

AUTHOR CONTRIBUTIONS: JTL measured histone binding affinity of ATAD2B mutant proteins via ITC, contributed to the X-ray structure solution, carried out NMR chemical shift perturbation experiments, circular dichroism experiments, created figures for the paper and wrote the first draft of the 
bioRxiv preprint doi: https://doi.org/10.1101/263624; this version posted February 11,2018 . The copyright holder for this preprint (which was not certified by peer review) is the author/funder, who has granted bioRxiv a license to display the preprint in perpetuity. It is made available under aCC-BY-NC-ND 4.0 International license.

Recognition of acetyllysine by the ATAD2B bromodomain

manuscript. JCG measured the binding affinity of histone ligands with WT ATAD2, carried out the sitedirected mutagenesis of two of the mutants and collected ITC data. JCG also assisted with creating figures for the NMR data. MT carried out the backbone assignment of ATAD2B, while GC collected all of the NMR chemical shift perturbation data. PN assisted with analysis of NMR chemical shift perturbations. SC prepared ${ }^{15} \mathrm{~N}$-labeled protein samples, assisted with NMR data analysis, and ITC binding affinity data collection and analysis. DLB and JEB were responsible for the synthesis and validation of compound 38. JLM contributed to the design of NMR experiments and protocols for data collection. KCG lead the experimental design of the study, data analysis, and contributed to the development of the manuscript figures and text. All authors contributed to the writing of the manuscript, reviewed the results and approved the final version of the manuscript.

\section{REFERENCES:}

[1] Leachman NT, Brellier F, Ferralli J, Chiquet-Ehrismann R, Tucker RP. ATAD2B is a phylogenetically conserved nuclear protein expressed during neuronal differentiation and tumorigenesis. Development, growth \& differentiation. 2010;52:747-55.

[2] Snider J, Thibault G, Houry WA. The AAA+ superfamily of functionally diverse proteins. Genome biology. 2008;9:216.

[3] Dhalluin C, Carlson JE, Zeng L, He C, Aggarwal AK, Zhou MM. Structure and ligand of a histone acetyltransferase bromodomain. Nature. 1999;399:491-6.

[4] Syntichaki P, Topalidou I, Thireos G. The Gen5 bromodomain co-ordinates nucleosome remodelling. Nature. 2000;404:414-7.

[5] Mujtaba S, He Y, Zeng L, Yan S, Plotnikova O, Sachchidanand, et al. Structural mechanism of the bromodomain of the coactivator CBP in 553 transcriptional activation. Mol Cell. 2004;13:251-63.

[6] Zhou J, Ma J, Zhang BC, Li XL, Shen SR, Zhu SG, et al. BRD7, a novel bromodomain gene, inhibits G1-S progression by transcriptionally regulating some important molecules involved in ras/MEK/ERK and Rb/E2F pathways. Journal of cellular physiology. 2004;200:89-98.

[7] Sanchez R, Zhou MM. The role of human bromodomains in chromatin biology and gene transcription. Curr Opin Drug Discov Devel. 2009;12:659-65.

[8] Avvakumov N, Lalonde ME, Saksouk N, Paquet E, Glass KC, Landry AJ, et al. Conserved molecular interactions within the HBO1 acetyltransferase complexes regulate cell proliferation. Mol Cell Biol.

2012;32:689-703.

[9] Verdin E, Ott M. 50 years of protein acetylation: from gene regulation to epigenetics, metabolism and beyond. Nature reviews Molecular cell biology. 2015;16:258-64.

[10] Filippakopoulos P, Picaud S, Mangos M, Keates T, Lambert JP, Barsyte-Lovejoy D, et al. Histone recognition and large-scale structural analysis of the human bromodomain family. Cell. 2012;149:214-31. [11] Lloyd JT, Glass KC. Biological function and histone recognition of family IV bromodomaincontaining proteins. Journal of cellular physiology. 2017.

[12] Flynn EM, Huang OW, Poy F, Oppikofer M, Bellon SF, Tang Y, et al. A Subset of Human Bromodomains Recognizes Butyryllysine and Crotonyllysine Histone Peptide Modifications. Structure. 2015;23:1801-14.

[13] Poplawski A, Hu K, Lee W, Natesan S, Peng D, Carlson S, et al. Molecular insights into the recognition of N-terminal histone modifications by the BRPF1 bromodomain. J Mol Biol.

2014;426:1661-76.

[14] Lubula MY, Eckenroth BE, Carlson S, Poplawski A, Chruszcz M, Glass KC. Structural insights into recognition of acetylated histone ligands by the BRPF1 bromodomain. FEBS Lett. 2014;588:3844-54.

[15] Poncet-Montange G, Zhan Y, Bardenhagen JP, Petrocchi A, Leo E, Shi X, et al. Observed bromodomain flexibility reveals histone peptide- and small molecule ligand-compatible forms of ATAD2. Biochem J. 2015;466:337-46. 
bioRxiv preprint doi: https://doi.org/10.1101/263624; this version posted February 11,2018 . The copyright holder for this preprint (which was not certified by peer review) is the author/funder, who has granted bioRxiv a license to display the preprint in perpetuity. It is made available under aCC-BY-NC-ND 4.0 International license.

Recognition of acetyllysine by the ATAD2B bromodomain

[16] Morozumi Y, Boussouar F, Tan M, Chaikuad A, Jamshidikia M, Colak G, et al. Atad2 is a generalist facilitator of chromatin dynamics in embryonic stem cells. Journal of molecular cell biology. 2016;8:34962.

[17] Koo SJ, Fernandez-Montalvan AE, Badock V, Ott CJ, Holton SJ, von Ahsen O, et al. ATAD2 is an epigenetic reader of newly synthesized histone marks during DNA replication. Oncotarget. 2016;7:7032335 .

[18] Boussouar F, Jamshidikia M, Morozumi Y, Rousseaux S, Khochbin S. Malignant genome reprogramming by ATAD2. Biochimica et biophysica acta. 2013;1829:1010-4.

[19] Altintas DM, Shukla MS, Goutte-Gattat D, Angelov D, Rouault JP, Dimitrov S, et al. Direct cooperation between androgen receptor and $\mathrm{E} 2 \mathrm{~F} 1$ reveals a common regulation mechanism for androgenresponsive genes in prostate cells. Molecular endocrinology. 2012;26:1531-41.

[20] Zhang M, Zhang C, Du W, Yang X, Chen Z. ATAD2 is overexpressed in gastric cancer and serves as an independent poor prognostic biomarker. Clinical \& translational oncology : official publication of the Federation of Spanish Oncology Societies and of the National Cancer Institute of Mexico.

2016;18:776-81.

[21] Luo Y, Ye GY, Qin SL, Yu MH, Mu YF, Zhong M. ATAD2 Overexpression Identifies Colorectal Cancer Patients with Poor Prognosis and Drives Proliferation of Cancer Cells. Gastroenterology research and practice. 2015;2015:936564.

[22] Krakstad C, Tangen IL, Hoivik EA, Halle MK, Berg A, Werner HM, et al. ATAD2 overexpression links to enrichment of B-MYB-translational signatures and development of aggressive endometrial carcinoma. Oncotarget. 2015;6:28440-52.

[23] Zheng L, Li T, Zhang Y, Guo Y, Yao J, Dou L, et al. Oncogene ATAD2 promotes cell proliferation, invasion and migration in cervical cancer. Oncology reports. 2015;33:2337-44.

[24] Wan WN, Zhang YX, Wang XM, Liu YJ, Zhang YQ, Que YH, et al. ATAD2 is highly expressed in ovarian carcinomas and indicates poor prognosis. Asian Pacific journal of cancer prevention : APJCP. 2014; 15:2777-83.

[25] Bamborough P, Chung CW, Furze RC, Grandi P, Michon AM, Sheppard RJ, et al. Structure-Based Optimization of Naphthyridones into Potent ATAD2 Bromodomain Inhibitors. J Med Chem.

2015;58:6151-78.

[26] Bamborough P, Chung CW, Demont EH, Furze RC, Bannister AJ, Che KH, et al. A Chemical Probe for the ATAD2 Bromodomain. Angewandte Chemie. 2016;55:11382-6.

[27] Fernandez-Montalvan AE, Berger M, Kuropka B, Koo SJ, Badock V, Weiske J, et al. Isoform-

Selective ATAD2 Chemical Probe with Novel Chemical Structure and Unusual Mode of Action. ACS Chem Biol. 2017.

[28] Zuiderweg ER. Mapping protein-protein interactions in solution by NMR spectroscopy.

Biochemistry. 2002;41:1-7.

[29] Crawford TD, Tsui V, Flynn EM, Wang SM, Taylor AM, Cote A, et al. Diving into the Water: Inducible Binding Conformations for BRD4, TAF1(2), BRD9, and CECR2 Bromodomains. Journal of Medicinal Chemistry. 2016;59:5391-402.

[30] Romero FA, Taylor AM, Crawford TD, Tsui V, Cote A, Magnuson S. Disrupting Acetyl-Lysine Recognition: Progress in the Development of Bromodomain Inhibitors. J Med Chem. 2016;59:1271-98. [31] Ciro M, Prosperini E, Quarto M, Grazini U, Walfridsson J, McBlane F, et al. ATAD2 is a novel cofactor for MYC, overexpressed and amplified in aggressive tumors. Cancer Res. 2009;69:8491-8.

[32] Caron C, Lestrat C, Marsal S, Escoffier E, Curtet S, Virolle V, et al. Functional characterization of ATAD2 as a new cancer/testis factor and a predictor of poor prognosis in breast and lung cancers.

Oncogene. 2010;29:5171-81.

[33] Kalashnikova EV, Revenko AS, Gemo AT, Andrews NP, Tepper CG, Zou JX, et al.

ANCCA/ATAD2 overexpression identifies breast cancer patients with poor prognosis, acting to drive 
Recognition of acetyllysine by the ATAD2B bromodomain

proliferation and survival of triple-negative cells through control of B-Myb and EZH2. Cancer Res. 2010;70:9402-12.

[34] Langini C, Caflisch A, Vitalis A. The ATAD2 bromodomain binds different acetylation marks on the histone H4 in similar fuzzy complexes. J Biol Chem. 2017;292:16734-45.

[35] Champagne KS, Piscitelli E, Francklyn CS. Substrate recognition by the hetero-octameric ATP phosphoribosyltransferase from Lactococcus lactis. Biochemistry. 2006;45:14933-43.

[36] Lee W, Bahrami A, Markley JL. ADAPT-NMR Enhancer: complete package for reduced dimensionality in protein NMR spectroscopy. Bioinformatics. 2013;29:515-7.

[37] Lee W, Hu K, Tonelli M, Bahrami A, Neuhardt E, Glass KC, et al. Fast automated protein NMR data collection and assignment by ADAPT-NMR on Bruker spectrometers. Journal of magnetic resonance. 2013;236C:83-8.

[38] Lee W, Westler WM, Bahrami A, Eghbalnia HR, Markley JL. PINE-SPARKY: graphical interface for evaluating automated probabilistic peak assignments in protein NMR spectroscopy. Bioinformatics. 2009;25:2085-7.

[39] Goddard TD, Kneller DG. Sparky3. University of California, San Francisco.

[40] Louis-Jeune C, Andrade-Navarro MA, Perez-Iratxeta C. Prediction of protein secondary structure from circular dichroism using theoretically derived spectra. Proteins. 2011.

[41] Garman E. Cool data: quantity AND quality. Acta Crystallogr D Biol Crystallogr. 1999;55:1641-53.

[42] McCoy AJ, Grosse-Kunstleve RW, Adams PD, Winn MD, Storoni LC, Read RJ. Phaser crystallographic software. Journal of applied crystallography. 2007;40:658-74.

[43] Emsley P, Cowtan K. Coot: model-building tools for molecular graphics. Acta Crystallogr D Biol Crystallogr. 2004;60:2126-32.

[44] Adams PD, Afonine PV, Bunkoczi G, Chen VB, Davis IW, Echols N, et al. PHENIX: a

comprehensive Python-based system for macromolecular structure solution. Acta Crystallogr D Biol Crystallogr. 2010;66:213-21.

[45] Davis IW, Leaver-Fay A, Chen VB, Block JN, Kapral GJ, Wang X, et al. MolProbity: all-atom contacts and structure validation for proteins and nucleic acids. Nucleic Acids Res. 2007;35:W375-83. [46] Urzhumtseva L, Afonine PV, Adams PD, Urzhumtsev A. Crystallographic model quality at a glance. Acta Crystallogr D Biol Crystallogr. 2009;65:297-300.

[47] Wallace AC, Laskowski RA, Thornton JM. LIGPLOT: a program to generate schematic diagrams of protein-ligand interactions. Protein Eng. 1995;8:127-34.

[48] Notredame C, Higgins DG, Heringa J. T-Coffee: A novel method for fast and accurate multiple sequence alignment. J Mol Biol. 2000;302:205-17. 


\section{Recognition of acetyllysine by the ATAD2B bromodomain}

\section{TABLES:}

Table 1. Binding of the ATAD2B bromodomain to acetylated histones. Dissociation constants of the interaction of histone tail peptides with the ATAD2B bromodomain measured by ITC titration experiments. Sequences of the acetylated histone peptides are also indicated.

\begin{tabular}{|l|l|l|l|}
\hline Histone peptide & Sequence & $\begin{array}{l}\text { ATAD2B ITC } \\
K_{\mathrm{D}}(\mu \mathrm{M})\end{array}$ & $\begin{array}{l}\text { ATAD2A } \\
\text { Reported } K_{\text {Ds }}\end{array}$ \\
\hline H2AK5ac (res 1-12)* & SGRGKacQGGKARA & $57.1 \pm 2.5$ & --- \\
\hline H4K5ac (res 4-17)* & GKacGGKGLGKGGAKR & No Binding & NA \\
\hline H4K5ac (res 1-10)* & SGRGKacGGKGL & $48.0 \pm 4.7$ & $\begin{array}{l}22 \mu \mathrm{M} \\
\text { (res 1-20) [15] }\end{array}$ \\
\hline H4K8ac (res 1-10)* & SGRGKGGKacGL & $1164.2 \pm 28.5$ & $\begin{array}{l}\text { NA, interaction } \\
\text { shown [17] }\end{array}$ \\
\hline H4K8ac (res 4-17)* & GKGGKacGLGKGGAKR & No Binding & NA \\
\hline H4K12ac (res 4-17)* & GKGGKGLGKacGGAKR & $135.9 \pm 9.0$ & $\begin{array}{l}2.5 \mu \mathrm{M} \\
\text { (res 1-25) [17] }\end{array}$ \\
\hline H4K12ac (res 1-15) & SGRGKGGKGLGKacGGA & $685.3 \pm 91.7$ & NA \\
\hline H4K16ac (res 10-20) & LGKGGAKacRHRK & No Binding & NA \\
\hline H4K5acK8ac (res 1-10) & SGRGKacGGKacGL & $28.1 \pm 1.6$ & --- \\
\hline H4K8acK12ac (res 6-15) & GGKacGLGKacGGA & No Binding & --- \\
\hline H4K12acK16ac (res 10-20) & LGKacGGAKacRHRK & $213.9 \pm 7.0$ & --- \\
\hline H4K5acK12ac (res 1-15) & SGRGKacGGKGLGKacGGA & $66.1 \pm 7.0$ & $\begin{array}{l}\text { NA, interaction } \\
\text { shown [17] }\end{array}$ \\
\hline H4 unmodified (res 4-17)* & GKGGKGLGKGGAKRHRK & No Binding & NA \\
\hline H3K9ac (res 1-12) & ARTKQTARKacSTG & No Binding & NA \\
\hline H3K14ac (res 8-19)* & RKSTGGKacAPRKQ & No Binding & $\begin{array}{l}\text { No binding } \\
\text { (res 1-21) [15] }\end{array}$ \\
\hline Compound 38 & & $\begin{array}{l}160.6 \pm 12.3 \\
\text { (nM) }\end{array}$ & \begin{tabular}{l} 
90 (nM) [25] \\
\hline *indicates peptides tested in NMR chemical shift perturbation experiments
\end{tabular} \\
\hline
\end{tabular}

Table 2. Binding of ATAD2B bromodomain mutant proteins with acetylated histones. Dissociation constants of the wild-type and mutant ATAD2B bromodomain proteins with histone ligands as measured by ITC experiments. $K_{D}$ value units are in $\mu \mathrm{M}$.

\begin{tabular}{|l|l|l|l|l|l|}
\hline ATAD2B bromo & $\begin{array}{l}\text { H2AK5ac } \\
\mathbf{( 1 - 1 2 )}\end{array}$ & $\begin{array}{l}\text { H4K5ac } \\
\mathbf{( 1 - 1 0 )}\end{array}$ & $\begin{array}{l}\text { H4K12ac } \\
\mathbf{( 4 - 1 7 )}\end{array}$ & $\begin{array}{l}\text { H4K5acK8ac } \\
\mathbf{( 1 - 1 0 )}\end{array}$ & H4 unmodified \\
\hline Wild type & $57.1 \pm 2.5$ & $48.0 \pm 4.7$ & $135.9 \pm 9.0$ & $28.1 \pm 1.6$ & No binding \\
\hline N1038A & $1697.0 \pm 524.0$ & $1153.3 \pm 170.0$ & No binding & $1429.2 \pm 172.0$ & No binding \\
\hline Y995A & No binding & No binding & No binding & No binding & No binding \\
\hline Y1037A & No binding & No binding & No binding & No binding & No binding \\
\hline
\end{tabular}


Recognition of acetyllysine by the ATAD2B bromodomain

Table 3. Secondary structure of ATAD2B bromodomain mutant proteins. Analysis of the secondary structure composition of the wild-type and mutant ATAD2B bromodomain proteins by circular dichroism.

\begin{tabular}{|l|l|l|}
\hline ATAD2B bromodomain & \% Alpha-helix & \% Beta-strand \\
\hline WT & $91.36 \%$ & $0.46 \%$ \\
\hline N1037A & $91.38 \%$ & $0.50 \%$ \\
\hline Y995A & $91.39 \%$ & $0.49 \%$ \\
\hline Y1037A & $91.39 \%$ & $0.49 \%$ \\
\hline
\end{tabular}

Table 4. Summary of the data collection and refinement statistics for the ATAD2B bromodomain in complex with $\mathbf{C - 3 8}$.

\begin{tabular}{|c|c|}
\hline (collection on a single crystal) & ATAD2B / compound 38 \\
\hline PDB code & $6 \mathrm{BSO}$ \\
\hline \multicolumn{2}{|l|}{ Data collection } \\
\hline Space group & $\mathrm{P} 66_{1} 22$ \\
\hline \multicolumn{2}{|l|}{ Cell dimensions } \\
\hline$a, b, c(\AA)$ & $78.422,78.422,111.672$ \\
\hline$\alpha, \beta, \gamma\left({ }^{\circ}\right)$ & $90,90,120$ \\
\hline Resolution $(\AA)$ & $43-2.2(2.28-2.2 *)$ \\
\hline R-pim (\%) & $3.6(24.9)$ \\
\hline $\mathrm{CC}_{1 / 2}$ & $0.93(0.825)$ \\
\hline Mean $I / \sigma(I)$ & $49.9(1.6)$ \\
\hline Completeness (\%) & $97.6(98.8)$ \\
\hline Redundancy & $3.9(3.9)$ \\
\hline \multicolumn{2}{|l|}{ Refinement } \\
\hline Resolution $(\AA)$ & $43-2.2$ \\
\hline No. unique reflections & 10600 \\
\hline $\mathrm{R}_{\text {work }} / \mathrm{R}_{\text {free }}$ & $19.2 / 23.1$ \\
\hline \multicolumn{2}{|l|}{ No. atoms: } \\
\hline Protein & 1062 \\
\hline Ligand/ion & 47 \\
\hline Waters & 21 \\
\hline \multicolumn{2}{|l|}{ Average B-factors $\left(\AA^{2}\right)$} \\
\hline Protein & 60.2 \\
\hline Ions & 73.1 \\
\hline Water & 56.8 \\
\hline Ligand C-38 & 57.3 \\
\hline \multicolumn{2}{|l|}{ R.M.S deviations: } \\
\hline Bond lengths $(\AA)$ & 0.009 \\
\hline Bond angles $\left({ }^{\circ}\right)$ & 1.05 \\
\hline \multicolumn{2}{|l|}{ Ramachandran plot (\%) } \\
\hline Favored & 97 \\
\hline Allowed & 3 \\
\hline Outliers & 0 \\
\hline Clash score & 5.1 \\
\hline
\end{tabular}

*Highest resolution shell is shown in parenthese. 
bioRxiv preprint doi: https://doi.org/10.1101/263624; this version posted February 11,2018 . The copyright holder for this preprint (which was not certified by peer review) is the author/funder, who has granted bioRxiv a license to display the preprint in perpetuity. It is made available under aCC-BY-NC-ND 4.0 International license.

Recognition of acetyllysine by the ATAD2B bromodomain

\section{FIGURE LEGENDS}

Figure 1. The ATAD2B bromodomain recognizes acetylated histones. (A) A schematic representation of the domain modules within the ATAD2B protein. (B) The family IV bromodomain containing proteins and the histone acetylation marks they are known to recognize.

Figure 2. ITC measurements of the interaction between acetylated histone ligands and the ATAD2B bromodomain. (A-P) Exothermic ITC enthalpy plots for the binding of the ATAD2B bromodomain to unmodified, mono- and di-acetylated histone ligands, as well as the ATAD2 bromodomain inhibitor compound 38. The calculated binding constants are indicated.

Figure 3. Interaction of the ATAD2B bromodomain with acetylated histone ligands. (A) Superimposed ${ }^{1} \mathrm{H}_{-}{ }^{15} \mathrm{~N}$ HSQC spectra of the ATAD2B bromodomain, collected during titration with the indicated histone peptides. The spectra are color-coded according to the protein/peptide ratio. (B) $2 \mathrm{D}{ }^{1} \mathrm{H}-$ ${ }^{15} \mathrm{~N}$ HSQC spectra of ${ }^{15} \mathrm{~N}$-labelled ATAD2B bromodomain annotated with the complete HSQC assignments.

Figure 4. Mapping of the mono- and di-acetylated histone ligand binding interfaces on the ATAD2B bromodomain. (A-E) The histograms show the normalized ${ }^{1} \mathrm{H}-{ }^{15} \mathrm{~N}$ chemical shift changes in the backbone amides of the ATAD2B bromodomain upon addition of peptides H4K5ac (1-10) (A), H4K8ac (1-10) (B), H4K5acK8ac (1-10) (C), H4K5ac (1-15) (D), and H4K5acK12ac (1-15) (E). Chemical shift changes from 0.2-0.3 ppm are colored yellow, while changes from 0.3-0.4 ppm are colored orange, and changes greater than $0.4 \mathrm{ppm}$ are colored in red on the surface representation of the apo ATAD2B bromodomain structure (PDBID: 3LXJ). (F) Cartoon representation of the ATAD2B bromodomain with the ZA loop region (residues 977-1004) colored in green while the extended region around the BC loop (residues 1031-1055) involved in chemical shift perturbations are colored magenta. The six amino acids residues exhibiting the largest chemical shift changes are labeled and shown in stick representation.

Figure 5. Proper protein folding of the mutant ATAD2B bromodomain. (A) Surface representation of the apo ATAD2B bromodomain showing the location of specific point mutations introduced into the binding pocket by site-directed mutagenesis. (B) Circular dichroism spectra in the far-UV region of the ATAD2B bromodomain wild-type and mutant proteins. The percent alpha-helical content of each protein is listed in the insert.

Figure 6. Coordination of bromodomain inhibitor molecules by the ATAD2 and ATAD2B bromodomains. (A) The ATAD2B bromodomain in complex with compound 38. (B) The ATAD2 bromodomain in complex with compound 42. Hydrogen bonds are indicated by a red dashed line, weaker contacts based on electron density are shown in grey. (C) Ligplot representation of the ATAD2B bromodomain binding pocket coordination of inhibitor compound 38. (D) Ligplot representation of the ATAD2 bromodomain binding pocket coordination of inhibitor compound 42. A red dashed line indicates hydrogen bonds while a red spiked semicircle marks hydrophobic interactions. Plots were generated using the LigPlus software [47]. (E) The simulated annealing composite omit map (yellow) representing the bound compound 38 (grey) in complex with the ATAD2B bromodomain (cyan) contoured at $1 \sigma .(\mathrm{F})$ Isolated image of the simulated annealing composite omit map (yellow) around compound 38 (grey) contoured at $1 \sigma$. The simulated annealing composite omit map shown in (E) and (F) was calculated prior to building the ligand into the structure. 
bioRxiv preprint doi: https//doi.org/10.1101/263624; this version posted February 11 2018. The copyright holder for this preprint (which was

Figure 1 not certified by peer review) is the author/funder, who has granted bioRxiv a license to display the preprint in perpetuity. It is made available under aCC-BY-NC-ND 4.0 International license.

\section{A}

1 ATAD2B

B
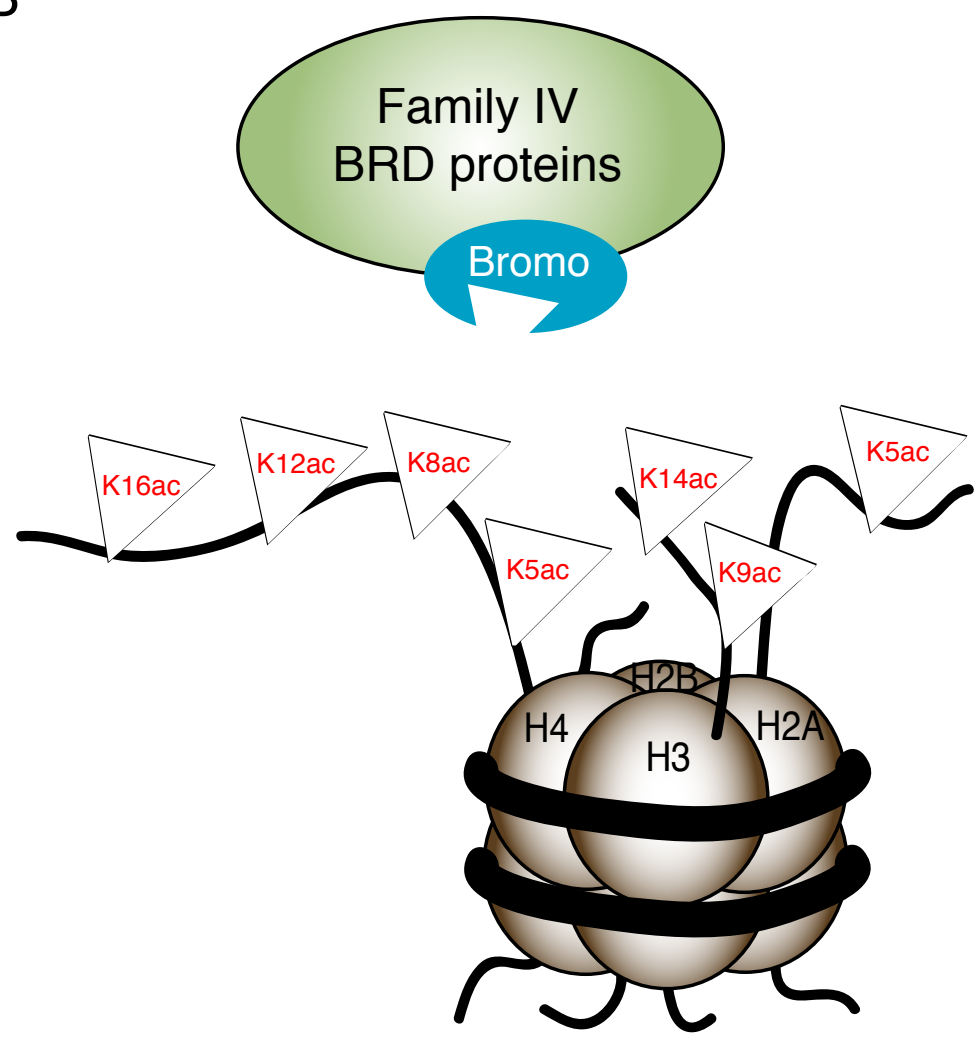
Figure 2

A

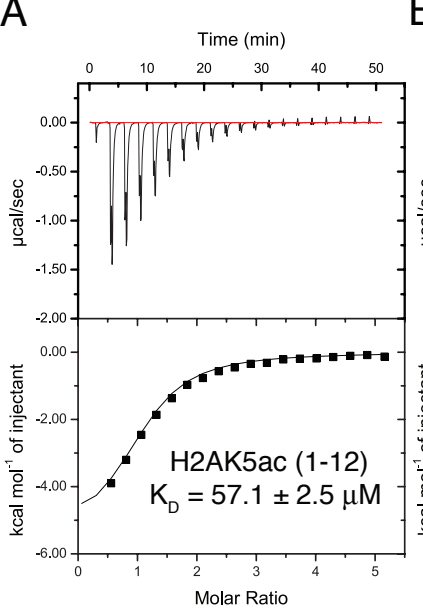

B

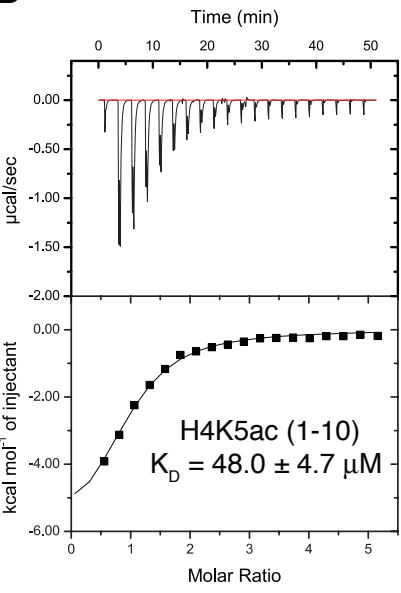

$\mathrm{F}$

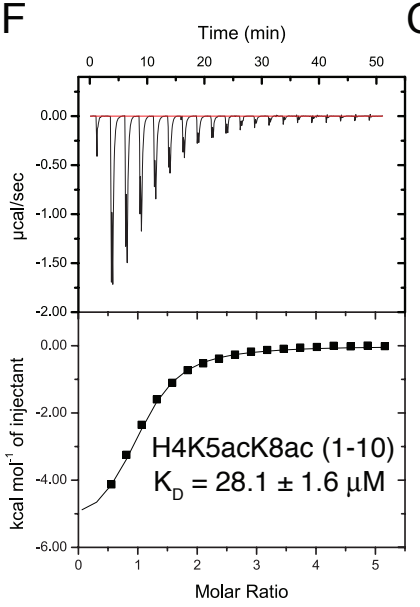

K

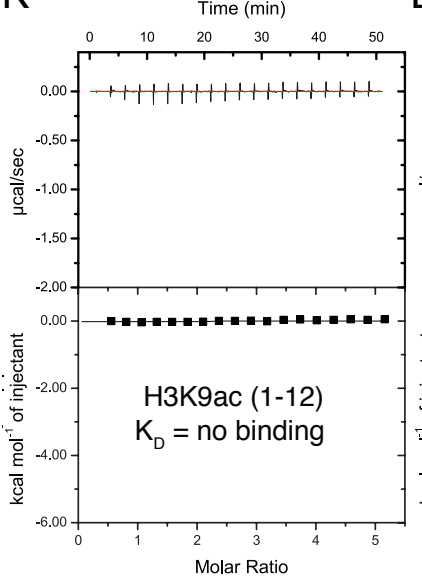

G

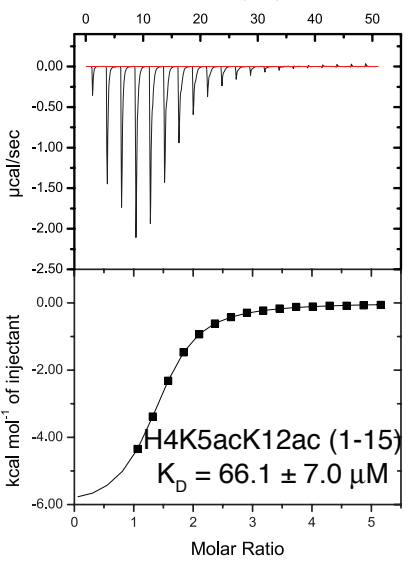

L

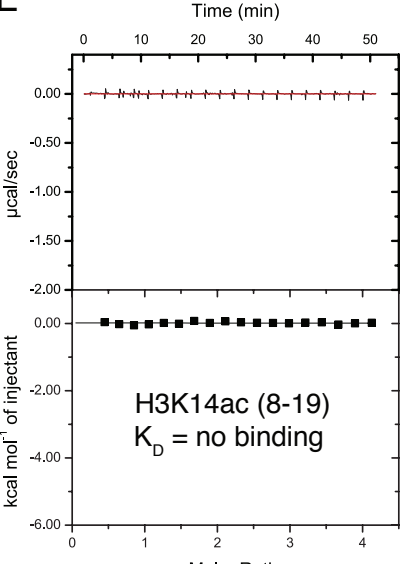

Molar Ratio
C

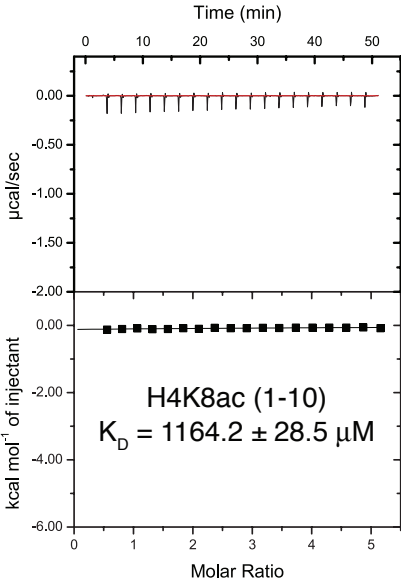

$\mathrm{H}$

Time (min)

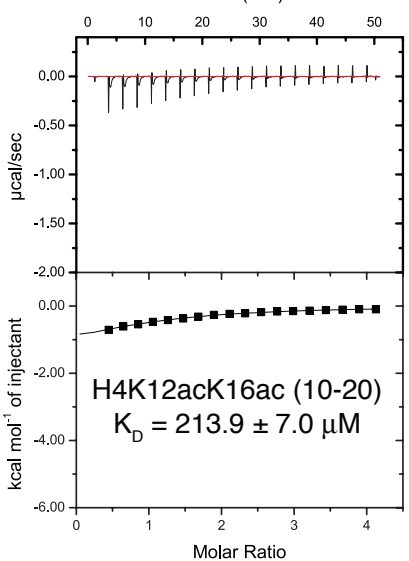

M

Time (min)

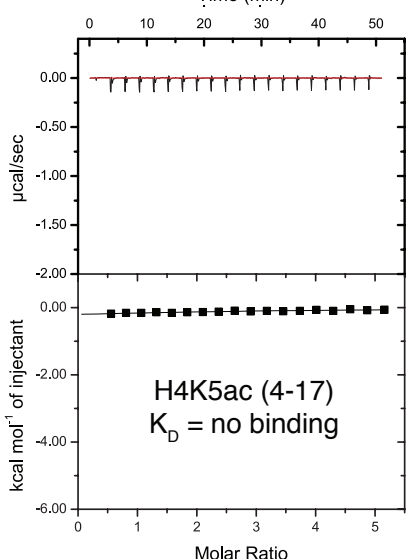

D

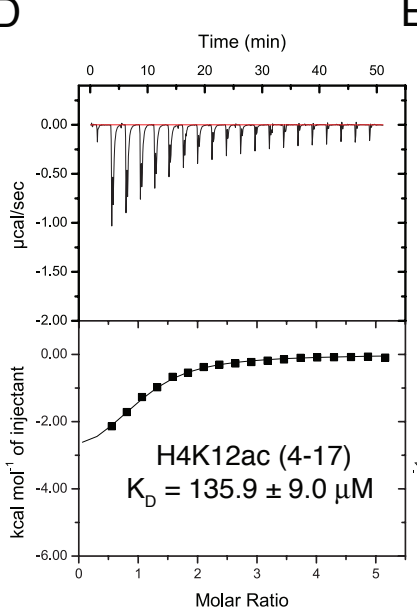

E

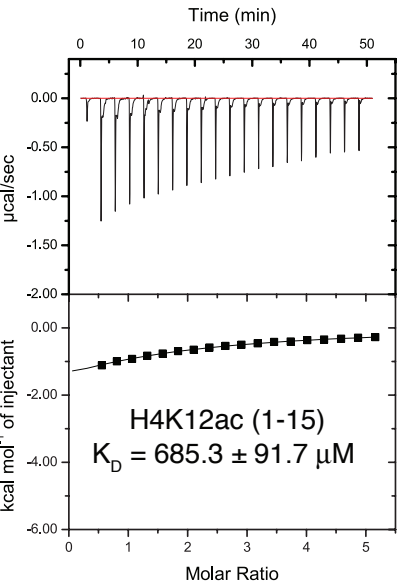

J
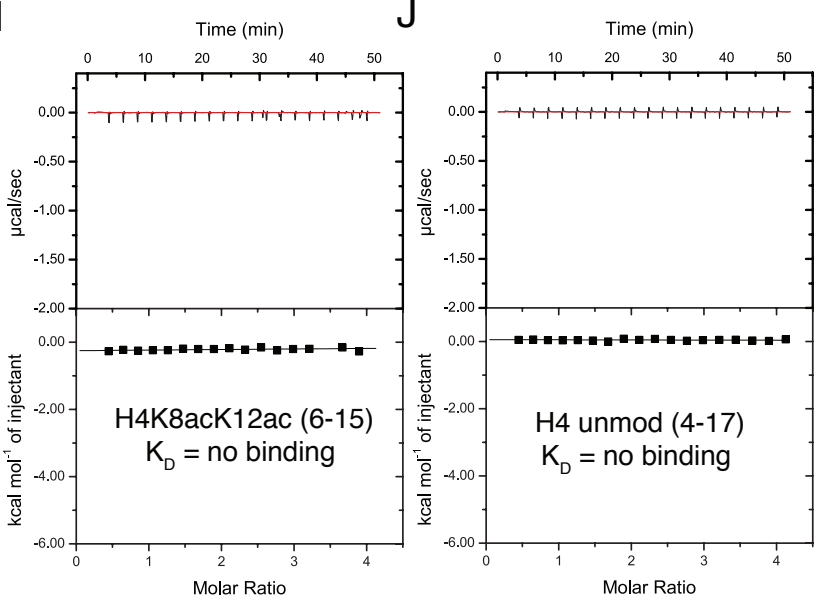

$\mathrm{N}$

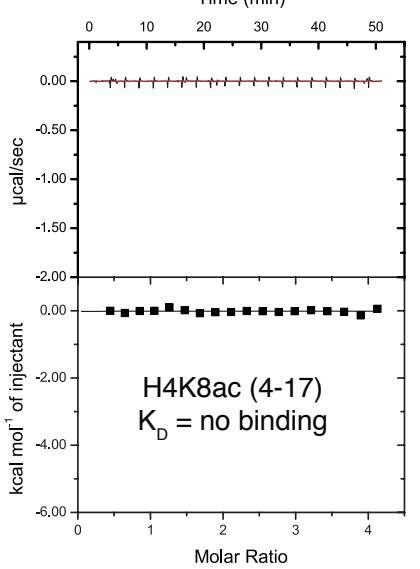

O

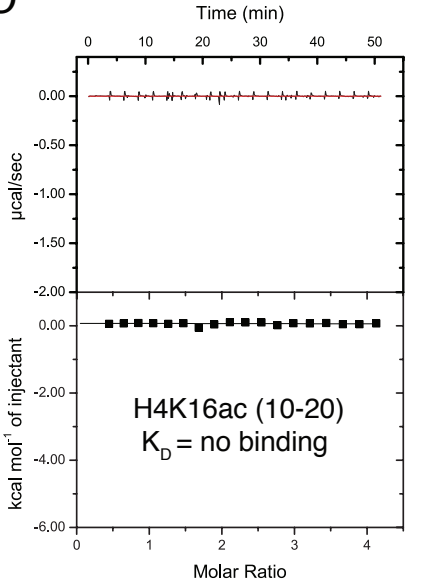

$\mathrm{P}$

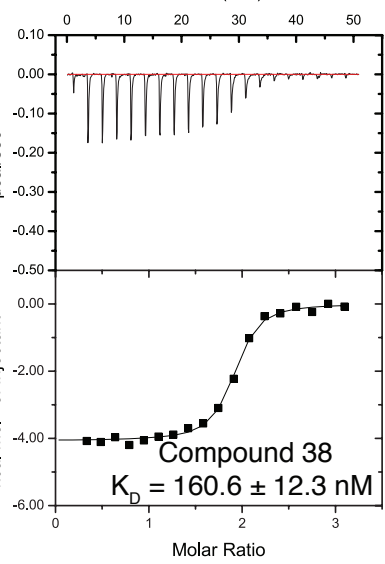


Figure 3

A
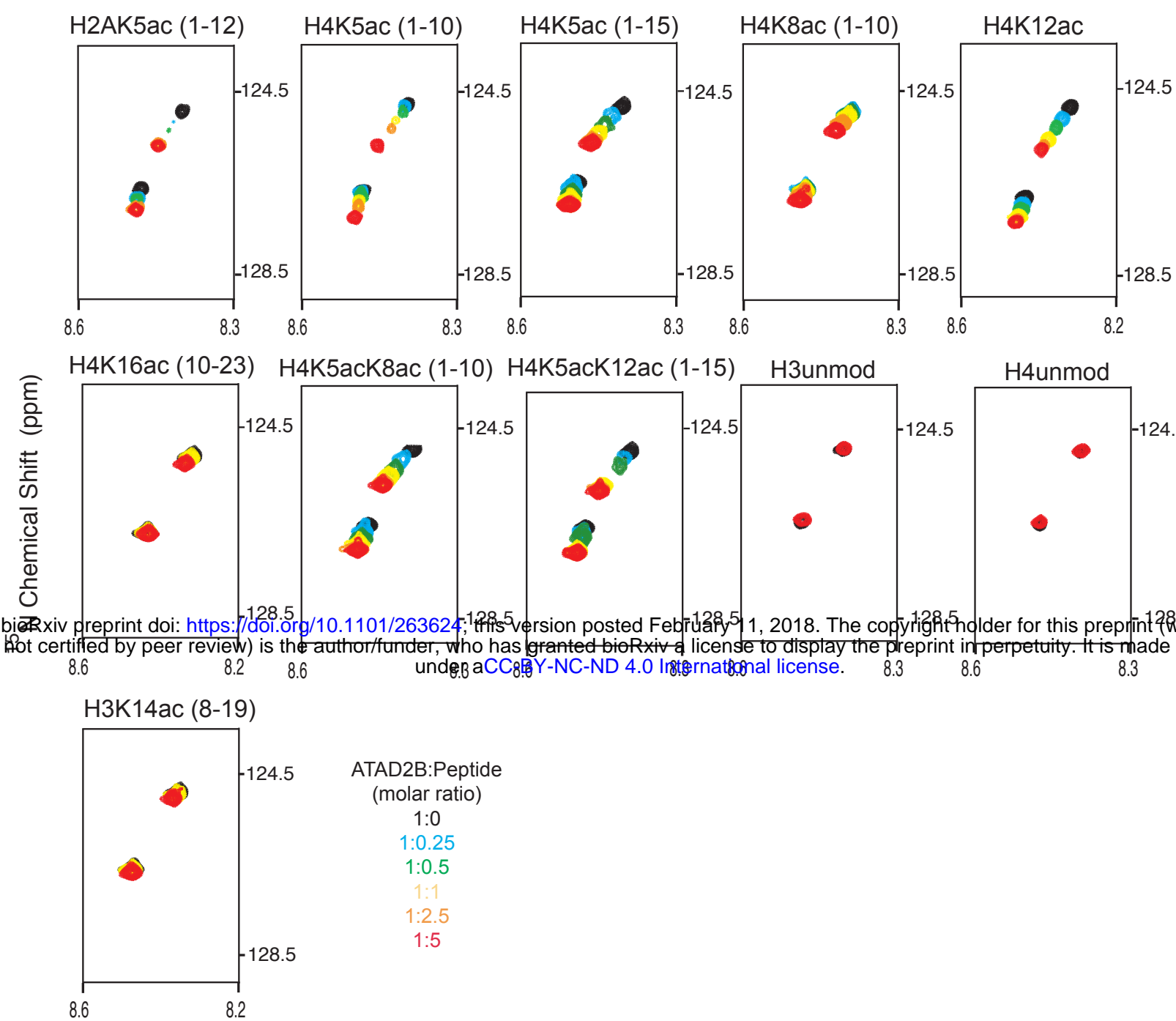

${ }^{1} \mathrm{H}$ Chemical Shift (ppm)

B

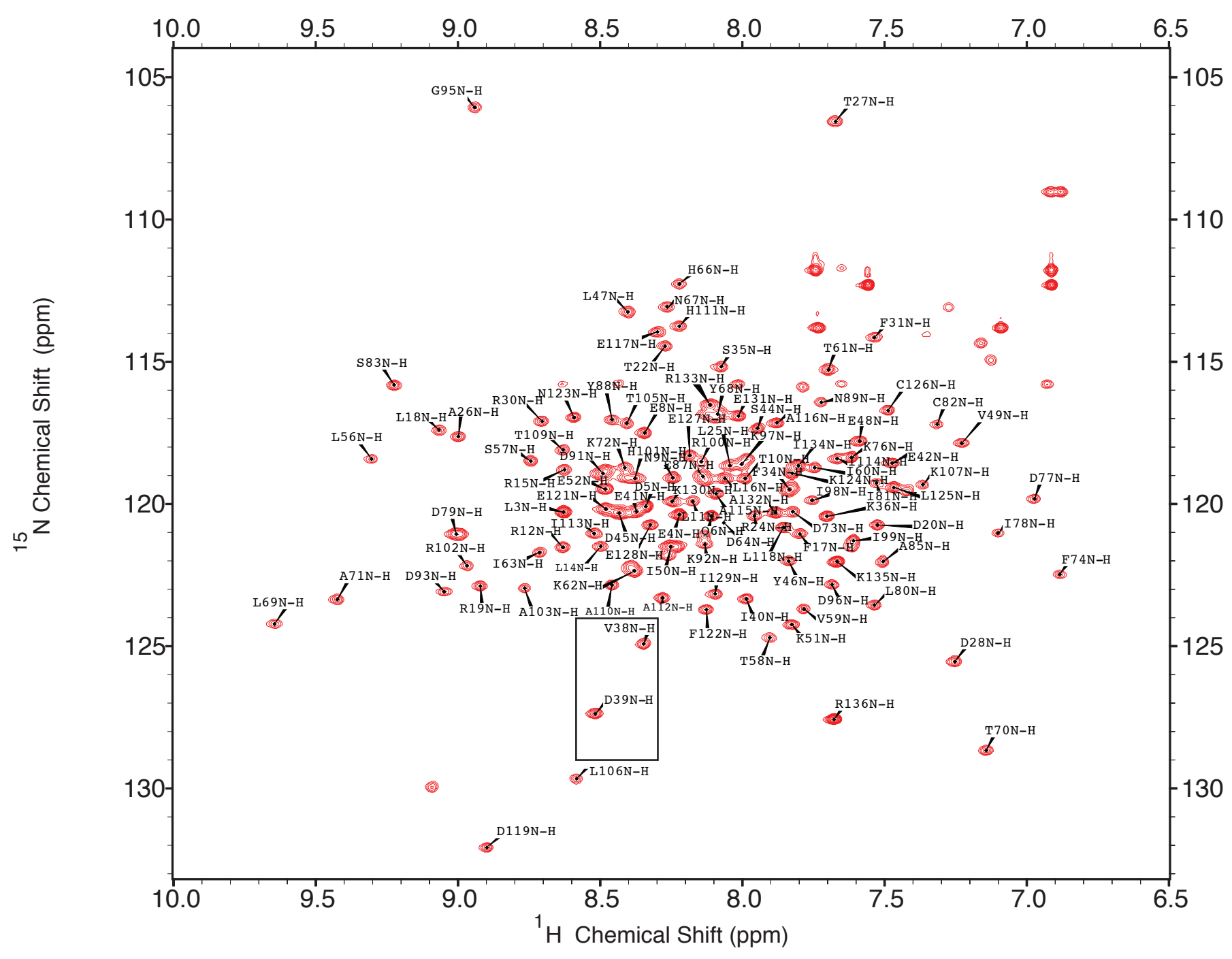


Figure 4

A ATAD2B x H4K5ac (1-10)

B

ATAD2B x H4K8ac (1-10)

C ATAD2B x H4K5acK8ac (1-10)
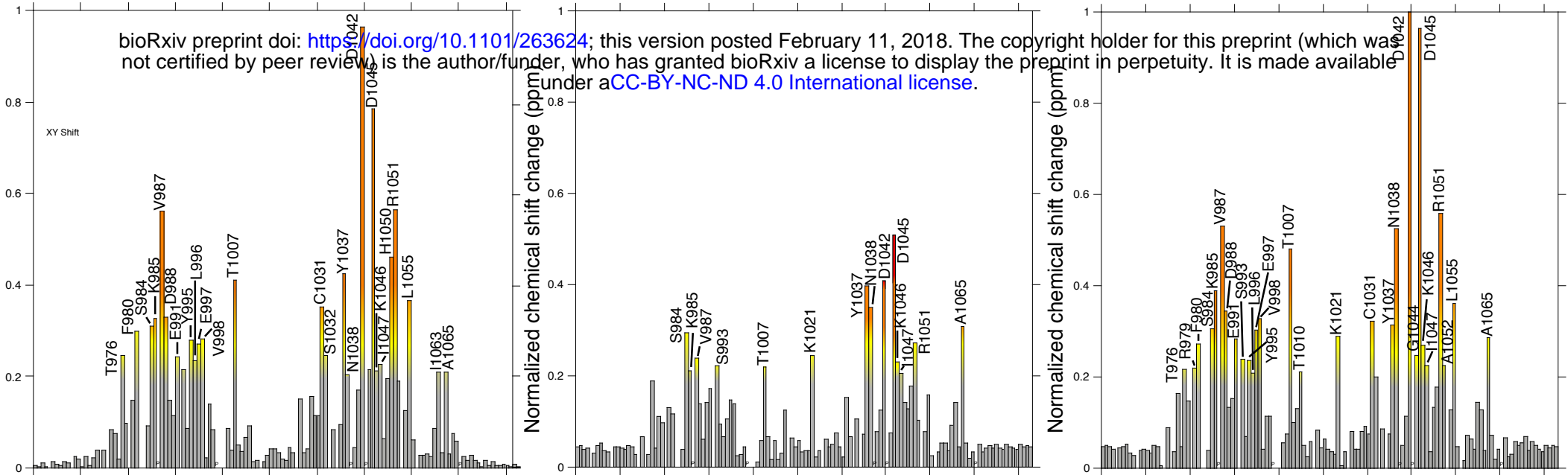

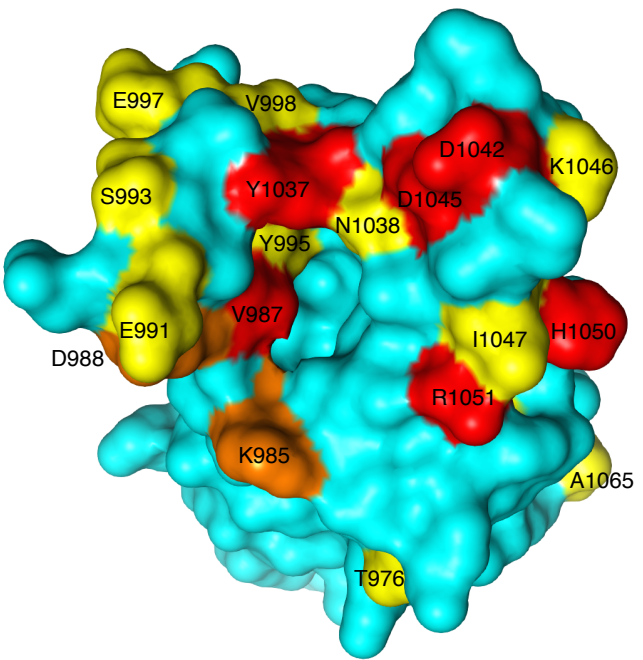

D
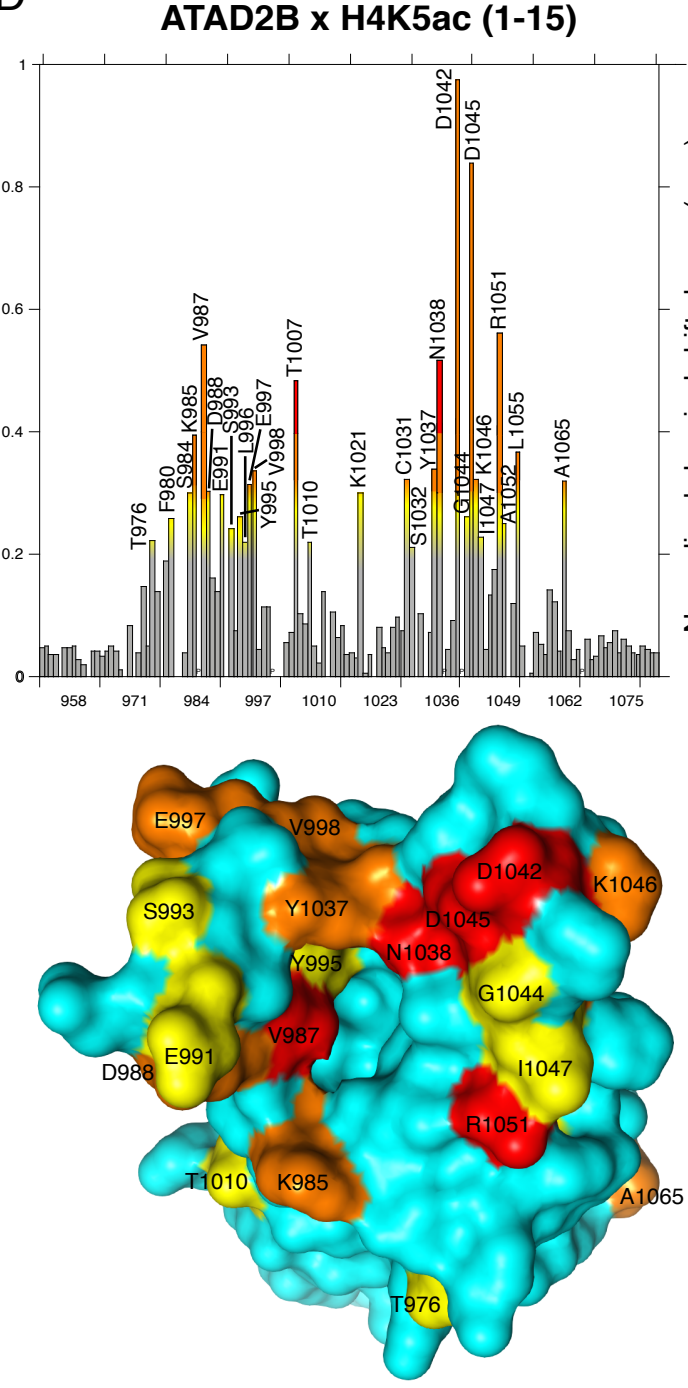

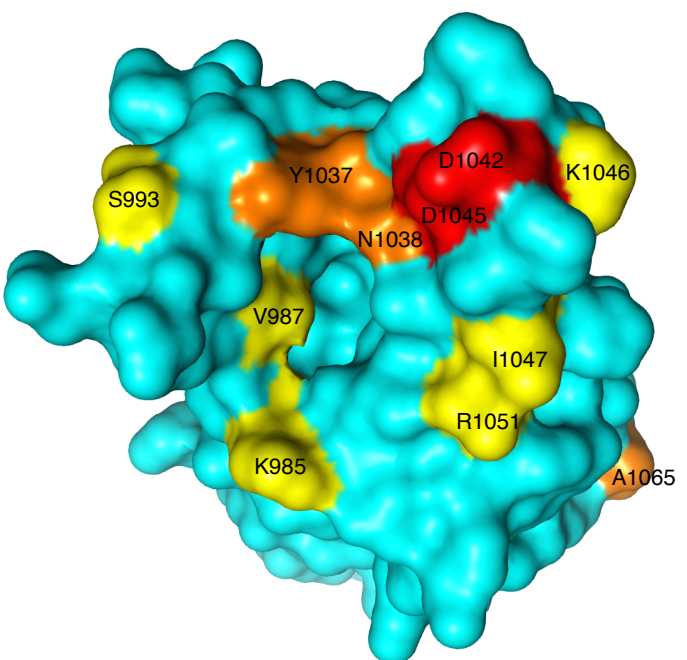

E ATAD2B x H4K5acK12ac (1-15)
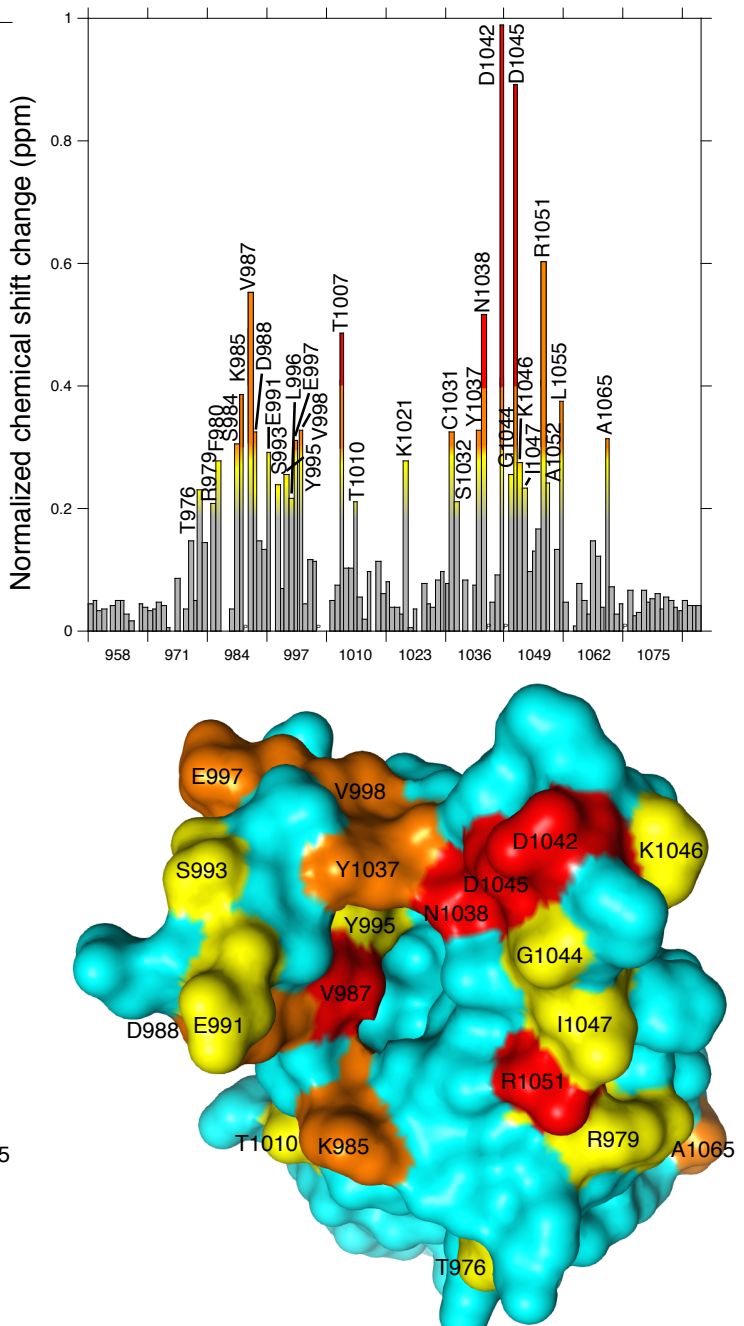

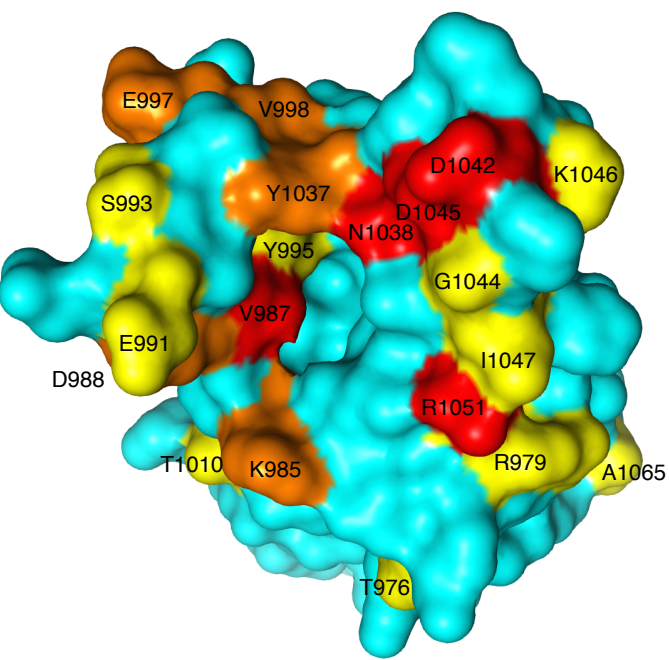

F

BC-Loop

(Tyr1037-Asp1042)

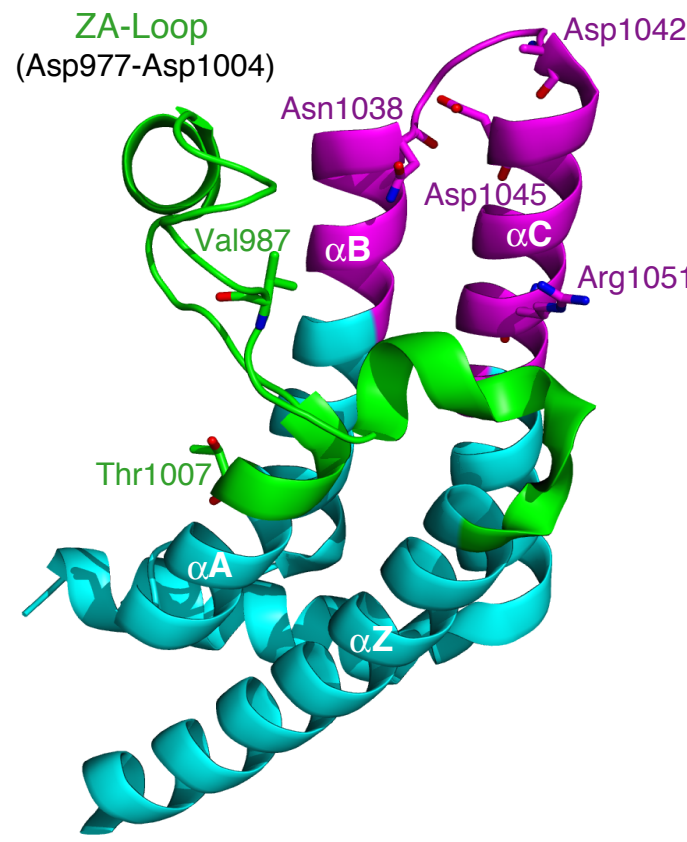


bioRxiv preprint doi: https://doi.org/10.1101/263624; this version posted February 11,2018 . The copyright holder for this preprint (which was not certified by peer review) is the author/funder, who has granted bioRxiv a license to display the preprint in perpetuity. It is made available Figure 5 not certified by peer review) is the author/funder, who has granted bioRxiv a license to display the
under aCC-BY-NC-ND 4.0 International license.

A

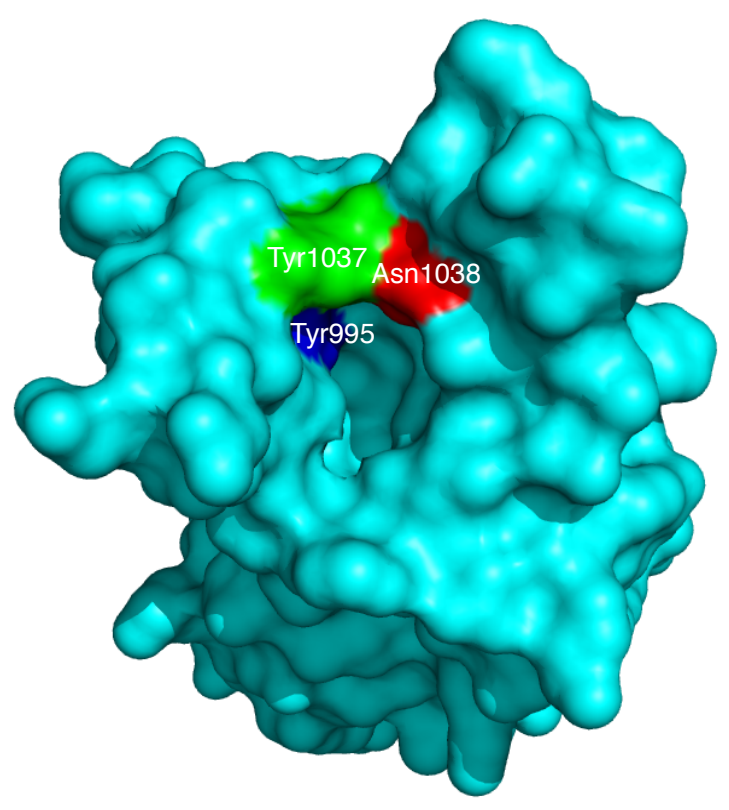

B

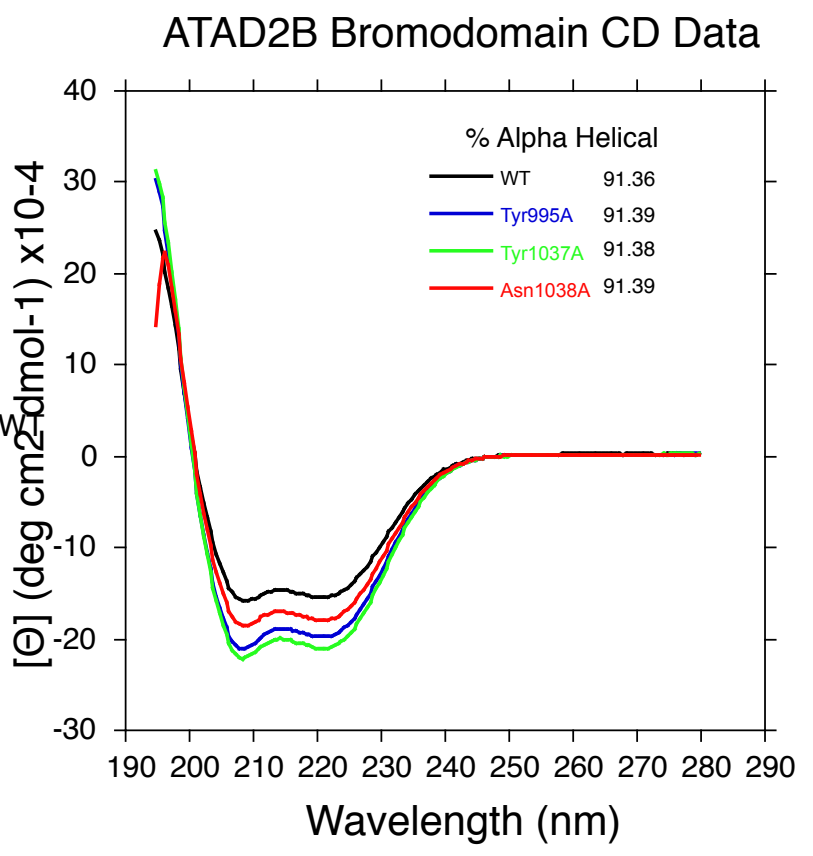


A

ATAD2B x Compound 38

B

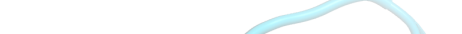

ATAD2 x Compound 42

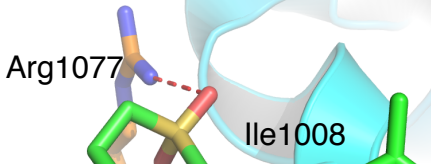

Asp1014

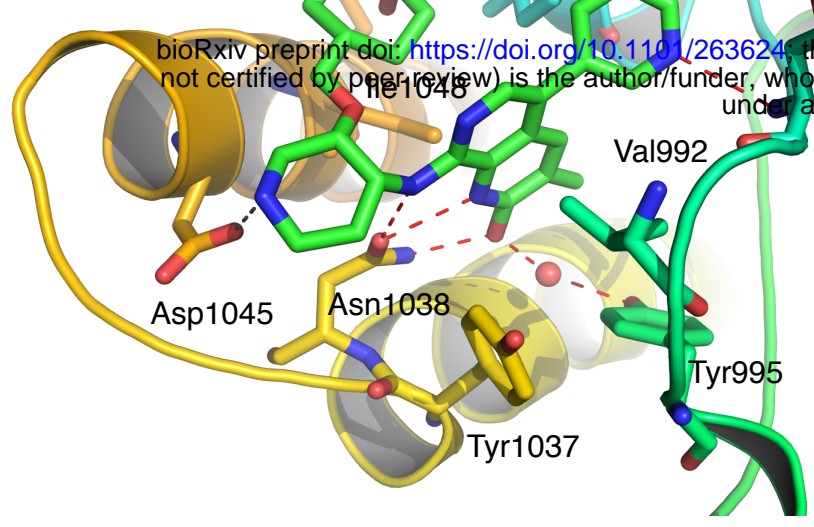

C

ATAD2B $x$ Compound 38

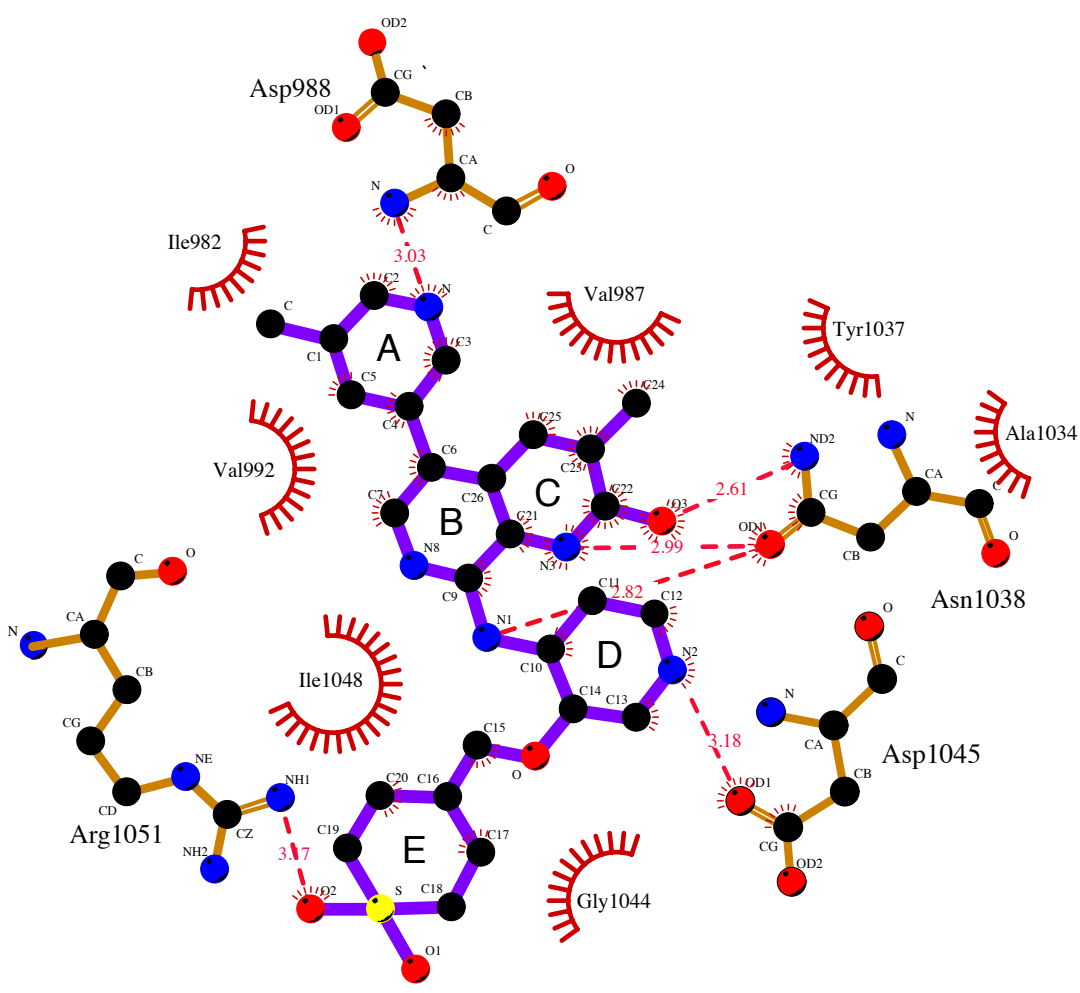

E

ATAD2B x Compound 38

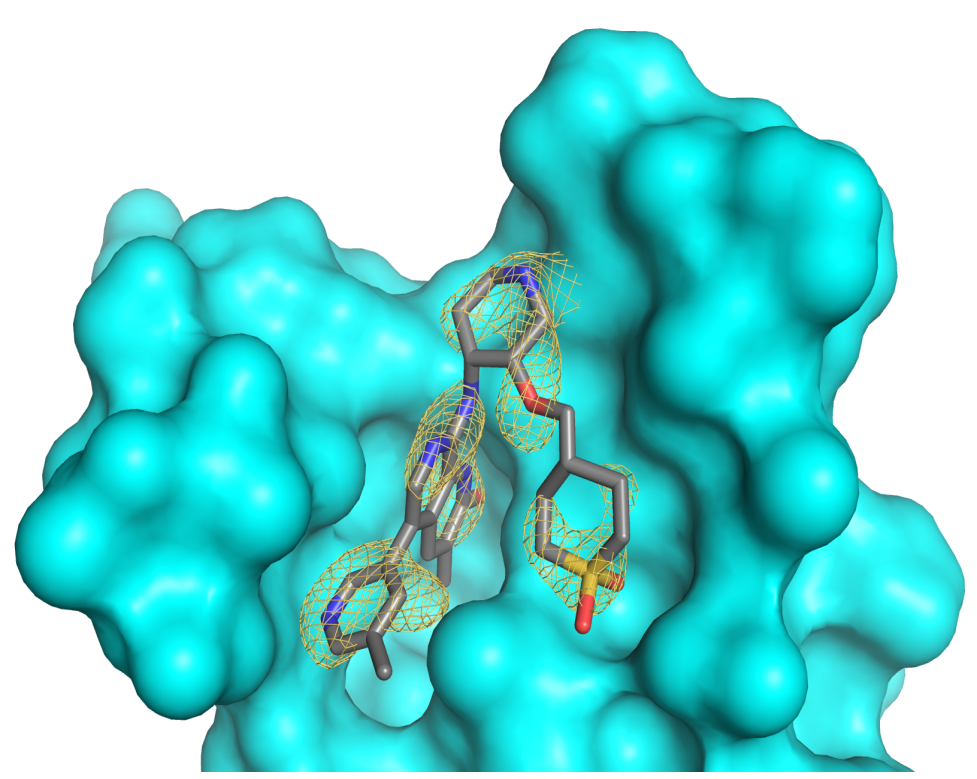

F

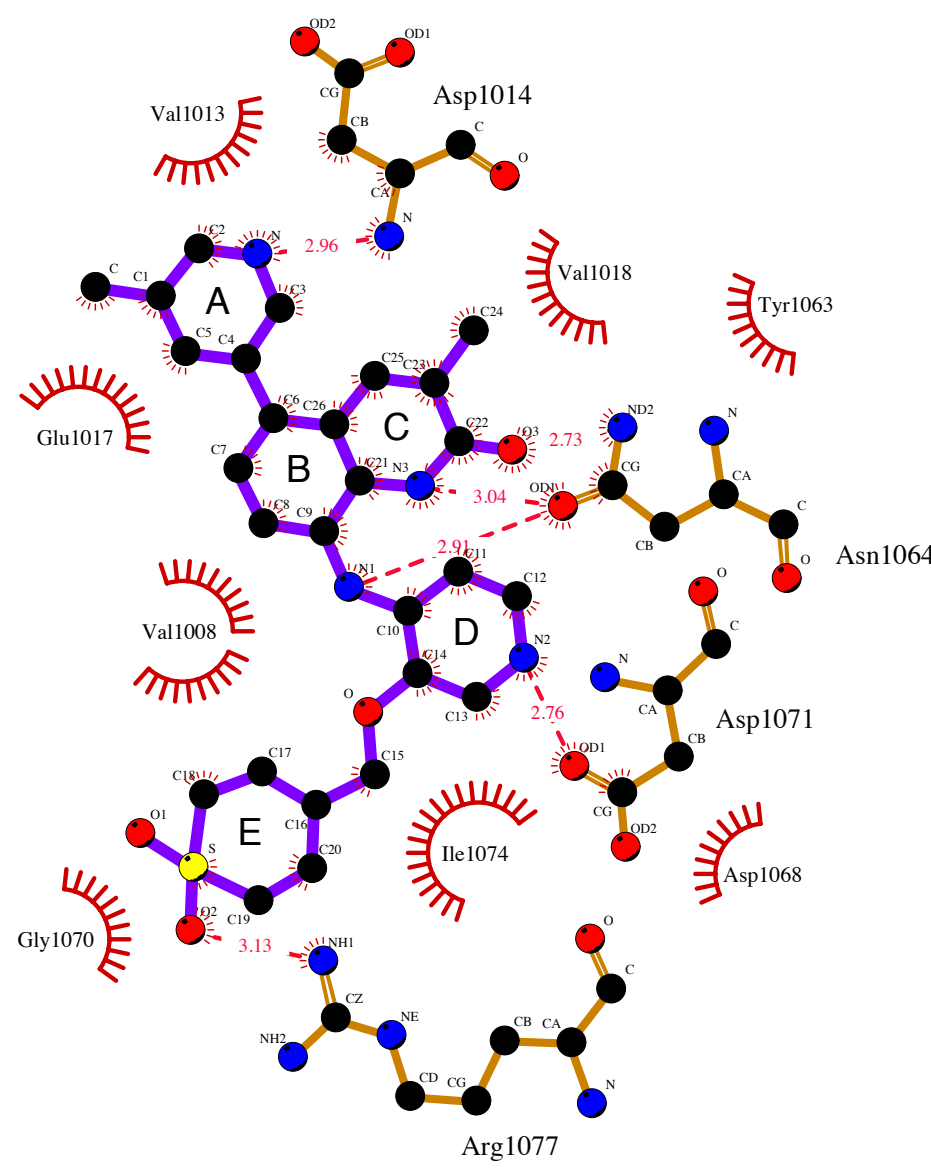

Compound 38

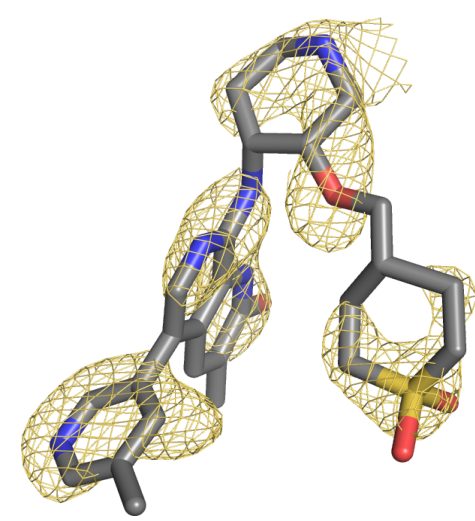

